\title{
Leveraging Pseudomonas Stress Response Mechanisms for Industrial Applications
}

\author{
Kelly Craig ${ }^{1 *}$, Brant R. Johnson ${ }^{1}$ and Amy Grunden ${ }^{2}$ \\ ${ }^{1}$ AgBiome Inc., Research Triangle Park, NC, United States, ${ }^{2}$ Department of Plant and Microbial Biology, North Carolina \\ State University, Raleigh, NC, United States
}

Members of the genus Pseudomonas are metabolically versatile and capable of adapting to a wide variety of environments. Stress physiology of Pseudomonas strains has been extensively studied because of their biotechnological potential in agriculture as well as their medical importance with regards to pathogenicity and antibiotic resistance. This versatility and scientific relevance led to a substantial amount of information regarding the stress response of a diverse set of species such as Pseudomonas chlororaphis, P. fluorescens, P. putida, P. aeruginosa, and P. syringae. In this review, environmental and industrial stressors including desiccation, heat, and cold stress, are cataloged along with their corresponding mechanisms of survival in Pseudomonas. Mechanisms of survival are grouped by the type of inducing stress with a focus on adaptations such as synthesis of protective substances, biofilm formation, entering a non-culturable state, enlisting chaperones, transcription and translation regulation, and altering membrane composition. The strategies Pseudomonas strains utilize for survival can be leveraged during the development of beneficial strains to increase viability and product efficacy.

Keywords: stress, Pseudomonas, formulation, heat, desiccation, cold, biofilm, chaperone

\section{INTRODUCTION}

Members of the genus Pseudomonas have drawn interest for their biotechnology and agricultural potential along with their medical importance as plant and human pathogens. There are 122 recognized and validly published species according to the List of Prokaryotic Names with Standing in Nomenclature (Parte, 2018). Some of the major species groupings are $P$. aeruginosa, $P$. chlororaphis, P. fluorescens, P. putida, and P. syringae (Gomila et al., 2015). Several species including $P$. putida and $P$. fluorescens have been used for degradation of phenol and other environmental pollutants (Wasi et al., 2013). There are also plant beneficial species such as $P$. chlororaphis that have been utilized as biopesticides to control microbial pathogens, insects, and nematodes (Anderson and Kim, 2018). The plant pathogen P. syringae has been studied for its broad host range in commercial crops and the resulting yield reduction (Valencia-Botín and Cisneros-López, 2012). The opportunistic pathogen $P$. aeruginosa is known for infecting immunocompromised individuals and has a natural resistance to many antibiotics (Priebe and Goldberg, 2014).

Pseudomonas species have been isolated from all over the world from the cold deserts of the trans-Himalayas to deep-sea hydrothermal vents of Juan de Fuca Ridge (Wang et al., 2002; Vyas et al., 2009). Pseudomonas species have not only been isolated from extreme environments, but 
they have also been found to colonize and promote plant growth under extreme temperature and drought conditions (Rolli et al., 2015; Subramanian et al., 2016). Pseudomonas strains are exposed to drought, temperature extremes, and many other environmental stressors in nature and have evolved mechanisms to survive these harsh conditions (Figure 1). This review covers the impact of stress exposure on cellular functions and the stress response mechanisms Pseudomonas species have adapted to survive these harsh conditions (Table 1). There is a focus on industrially relevant stresses and formulation strategies to improve viability and efficacy during product development.

\section{DESICCATION STRESS}

Semi-arid regions cover approximately $15 \%$ of the earth's land surface, and these regions are predicted to continue expanding due to climate change and desertification (Huang et al., 2015). Desiccation stress is frequent in semi-arid regions, and it can temporarily occur in other regions due to seasonal changes, droughts, wet-dry cycles, or a number of other natural causes. Bacteria that are able to survive under these conditions of reduced water availability are called xerotolerant. Some Pseudomonas species have moderate resistance to dehydration including many $P$. fluorescens endophytes that colonize roots and have developed mechanisms to persist through drought (Schnider-Keel et al., 2001; Ali et al., 2013; Pravisya et al., 2018).

Bacteria can be exposed to desiccation stress in the natural environment, but this stress can also hinder survival during industrial processes necessary for formulating beneficial, pathogen suppressing bacteria for application onto crops. During the formulation process, products containing beneficial bacteria can be dried to halt metabolism and improve shelf-life stability. Spray drying, fluidized bed drying, and freeze drying are all drying methods to preserve a product through the removal of moisture (Berninger et al., 2018). The stress of dehydration is taken into consideration when selecting a formulation process, and protectants can be added to improve viability (Bashan et al., 2014).

Using desiccation as a means to preserve bacteria is a delicate process. Water is critical for survival by providing cell structure and supporting vital molecules including proteins and nucleic acids (Esbelin et al., 2018). Dehydration can result in a loss of membrane integrity, a disruption of major biosynthesis and repair pathways, and a lethal accumulation of reactive oxygen species (Lebre et al., 2017). This common exposure in nature has led to the evolution of desiccation survival mechanisms in bacteria including the production of compatible solutes and biofilm formation (Figure 2).

\section{Compatible Solutes Overview}

Compatible solutes including simple sugars, heterosides, and amino acids are accumulated intracellularly to protect cells from heating, freezing, desiccation, and oxidative stress (Welsh, 2000). Compatible solutes balance osmotic pressure, help maintain cell turgor pressure, can be used as an energy source, and protect cellular structures against changes in water availability.
Studies have been conducted on many Pseudomonas strains demonstrating their ability to synthesize compatible solutes to overcome different types of stress (Kurz et al., 2010; Sandhya et al., 2010).

\section{Compatible Solutes - Trehalose}

One of the most well studied compatible solutes is the disaccharide trehalose. Trehalose is a stable, colorless nonreducing disaccharide that is used to stabilize products in cosmetics, food, and pharmaceuticals (Schiraldi et al., 2002). There are two proposed mechanisms to explain the desiccation protection properties of trehalose. The first mechanism is that trehalose provides protection by encasing biomolecules in a glass sugar matrix which halts molecular mobility and degradation (Jain and Roy, 2009). The second is the water replacement hypothesis which explains that trehalose protects the native protein conformation during drying by replacing the hydrogen bonds formed between water and the protein with hydrogen bonds formed between the trehalose hydroxyl group and the protein (Mensink et al., 2017).

The ability to accumulate and synthesize trehalose has been identified in Pseudomonas and is accomplished through the action of trehalose-P-synthase and trehalose-P-phosphatase enzymes encoded by ots $A$ and ots $B$ homologs (Lee et al., 2005; Park et al., 2007). The accumulation of trehalose by Pseudomonas sp. BCNU 106 was determined by measuring the total intracellular trehalose content, trehalase activity, and mRNA levels of the trehalose-biosynthetic genes (Park et al., 2007). Pseudomonas strains have been screened for the presence of trehalose synthase to produce trehalose from maltose. Trehalose synthase has been discovered in $P$. stutzeri and P. putida strains, and this enzyme has been cloned and expressed in Escherichia coli (E. coli) for scaled-up production (Lee et al., 2005; Wang et al., 2014). Trehalose has been demonstrated to protect Pseudomonas strains from toxic organic solvents, desiccation, salt stress, and other environmental stressors (Mikkat et al., 2000; Park et al., 2007; Freeman et al., 2010).

\section{Compatible Solutes - Glutamate}

Glutamate and the derivatives of this amino acid play essential roles in nitrogen metabolism and stress tolerance. Alpha ketoglutarate, an intermediate of the TCA Cycle, is utilized by $P$. fluorescens for detoxification of reactive oxygen species (Mailloux et al., 2009). Alpha ketoglutarate eliminates reactive oxygen species by reacting with hydrogen peroxide to form succinate, water, and carbon dioxide (Liu et al., 2018). During oxidative stress alpha ketoglutarate dehydrogenase is downregulated, leaving alpha ketoglutarate molecules to scavenge reactive oxygen species and protect the cell (Mailloux et al., 2009).

Glutamine synthetase was downregulated in $P$. syringae strains in response to osmotic shock (Freeman et al., 2013). Under these conditions, glutamine synthetase would no longer catalyze a conversion of glutamate to glutamine resulting in an accumulation of glutamate. Freeman and associates theorize glutamate may function as a counterion to positively charged potassium ions before transitioning to glutamine synthesis. This 


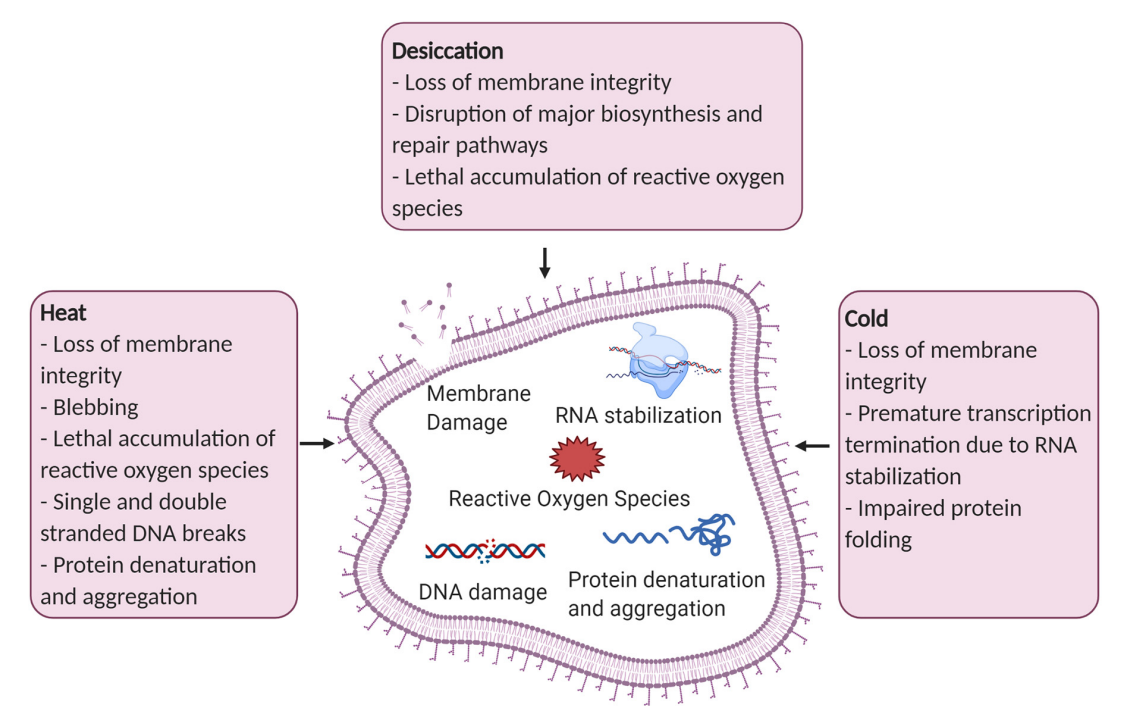

FIGURE 1 | Examples of cellular damage caused by desiccation, heat, and cold stress. Figure created with BioRender.com.

hypothesis for glutamates function in osmotic stress has also been demonstrated in studies conducted on the model organism E. coli (Cagliero and Jin, 2013). Exogenous potassium ions are brought into the cell to maintain the osmotic or turgor pressure after osmotic stress. To compensate for the net charge increase from the intake of potassium ions, glutamate is accumulated or synthesized so the net charge of the cytoplasm is preserved.

\section{Formulation Protectants}

Pseudomonas strains have developed numerous mechanisms to survive exposure to stress in the natural environment. The knowledge gained from studying bacterial mechanisms of survival can be applied to industrial processing. Protectants can be externally applied to beneficial strains to increase viability especially during the formulation process. The formulation process is necessary to enhance the storage capability, transportability, and ease of application in the field. Typically, bacterial strains are grown and harvested from broth, protectants are externally added to the harvested cells, then the cells are dried using methods such as spray drying or freeze drying (Berninger et al., 2018). Protectants can also be added to the medium during growth to be taken up and accumulated in the cell for a protective effect.

There are a number of protectants available including sugars (e.g., sucrose, trehalose, maltose, and lactose), polyols (e.g., mannitol, sorbitol, and glycerol), and amino acids (e.g., Lleucine, Glycine, and L-Proline). Research has been conducted to identify optimal protectants for the formulation of Pseudomonas biological control agents. One study was carried out to identify optimal osmoprotectants for three $P$. fluorescens strains capable of reducing Fusarium dry rot of potatoes (Schisler et al., 2016). The osmoprotectants glucose, fructose, trehalose, raffinose, and stachyose were applied to the strains before air drying. Fructose and trehalose were shown to be the most effective osmoprotectants overall though osmoprotectant influence on cell survival varied between strains. Lactose proved to be an optimal lyoprotectant for freeze drying and cold storage of a $P$. fluorescens strain utilized for the control of fire blight disease (Cabrefiga et al., 2014), whereas maltodextrin improved the viability after fluidized bed drying of a $P$. protegens strain capable of controlling bacterial wilt of tomatoes (Wang et al., 2020b). Elucidation of bacterial mechanisms of stress survival has informed the application of protectants during industrial fermentation and formulation processes and is an area of continued research interest for further refining and improving effectual protectant supplementation.

\section{Biofilms and Exopolysaccharide Secretion}

Biofilms are composed of a complex consortium of microorganisms that are adhered to a surface and are encased in an extracellular matrix. The extracellular matrix is composed of extracellular polymeric substances (EPSs) secreted by the cells living in the biofilm such as polysaccharides, proteins, glycoproteins, glycolipids, and extracellular DNA (Flemming et al., 2007; Lopez et al., 2010). The EPS primarily functions to maintain biofilm integrity and to provide protection against desiccation and other stresses. Biofilm formation supports the transition of formerly vegetative cells to non-dividing, antibiotic resistant persister cells, which further enhances their resistance to biotic and abiotic stresses (Lopez et al., 2010).

Polysaccharides are a predominant component of biofilms and help facilitate aggregation, adherence, and surface tolerance (Mann and Wozniak, 2012). Alginate is an exopolysaccharide that plays a major role in Pseudomonas biofilm formation by affecting the biofilm structure and stress resistance (Hentzer et al., 2001). Alginate protects cells from water limitation by controlling biofilm architecture and hydration (Gulez et al., 2014). Alginate absorbs and retains water allowing cells to stay hydrated long enough to metabolically adjust to desiccation 
TABLE 1 | Overview of bacterial survival mechanisms against desiccation, heat, and cold stress and examples of industrially relevant stress mitigation processes.

\begin{tabular}{|c|c|c|c|c|c|}
\hline Stress & Effect of stress & $\begin{array}{l}\text { Mechanism of } \\
\text { resistance }\end{array}$ & $\begin{array}{l}\text { Effect of resistance } \\
\text { mechanism }\end{array}$ & $\begin{array}{l}\text { Industrially relevant } \\
\text { stress mitigation } \\
\text { process }\end{array}$ & References \\
\hline \multirow[t]{3}{*}{ Desiccation } & $\begin{array}{l}\text { Damage to cell membrane, } \\
\text { accumulation of reactive } \\
\text { oxygen species, and loss of } \\
\text { protein function. }\end{array}$ & $\begin{array}{l}\text { Accumulation of } \\
\text { Compatible Solutes } \\
\text { (Trehalose, } \\
\text { Alpha-ketoglutarate) }\end{array}$ & $\begin{array}{l}\text { Trehalose replaces water and } \\
\text { forms protective matrix. } \\
\text { Glutamate eliminates reactive } \\
\text { oxygen species. }\end{array}$ & $\begin{array}{l}\text { Addition of protectants for } \\
\text { formulation. }\end{array}$ & $\begin{array}{l}\text { Jain and Roy, 2009; } \\
\text { Mailloux et al., 2009; } \\
\text { Mensink et al., } 2017\end{array}$ \\
\hline & & Biofilms & $\begin{array}{l}\text { Increases persister cells and } \\
\text { forms an exracellular matrix } \\
\text { barrier. }\end{array}$ & $\begin{array}{l}\text { Fermentation } \\
\text { contamination and } \\
\text { maintenance. }\end{array}$ & Lopez et al., 2010 \\
\hline & & $\begin{array}{l}\text { Exopolysaccharide } \\
\text { secretion (Alginate) }\end{array}$ & $\begin{array}{l}\text { Water retention and controls } \\
\text { biofilm architecture. }\end{array}$ & $\begin{array}{l}\text { Polymer encapulation for } \\
\text { formulation. }\end{array}$ & $\begin{array}{l}\text { Chang et al., 2007; } \\
\text { Gulez et al., } 2014\end{array}$ \\
\hline \multirow[t]{4}{*}{ Heat } & $\begin{array}{l}\text { Loss of membrane } \\
\text { permeability, DNA damage, } \\
\text { and denatured Proteins. }\end{array}$ & $\begin{array}{l}\text { Chaperone } \\
\text { (GroEL/GroES or } \\
\text { DnaK/DnaJ/GrpE } \\
\text { systems) }\end{array}$ & Correct misfolded proteins. & $\begin{array}{l}\text { Regulation of cyclic } \\
\text { lipopeptides. }\end{array}$ & $\begin{array}{l}\text { Mayer et al., 2000; Alix, } \\
\text { 2006; Georgescauld } \\
\text { et al., } 2014\end{array}$ \\
\hline & & $\begin{array}{l}\text { Protease Systems } \\
\text { (ClpAP) }\end{array}$ & $\begin{array}{l}\text { Catalyze the breakdown of } \\
\text { proteins. }\end{array}$ & $\begin{array}{l}\text { Regulation of cyclic } \\
\text { lipopeptides. }\end{array}$ & $\begin{array}{l}\text { Richter et al., 2010; } \\
\text { Meyer and Baker, } 2011\end{array}$ \\
\hline & & Thermosensor (ROSE) & $\begin{array}{l}\text { Regulates expression of stress } \\
\text { response. }\end{array}$ & $\begin{array}{l}\text { Regulation of rhamnolipid } \\
\text { production. }\end{array}$ & $\begin{array}{l}\text { Nocker et al., 2001; } \\
\text { Vinella et al., 2005; } \\
\text { Narberhaus, } 2010\end{array}$ \\
\hline & & $\begin{array}{l}\text { Alternative sigma } \\
\text { factors (sigma 32) }\end{array}$ & $\begin{array}{l}\text { Controls transcription of stress } \\
\text { related genes. }\end{array}$ & $\begin{array}{l}\text { Resistance to desiccation } \\
\text { in soil environments. }\end{array}$ & $\begin{array}{l}\text { Potvin et al., 2008; } \\
\text { Thakur et al., } 2013\end{array}$ \\
\hline \multirow[t]{3}{*}{ Cold } & $\begin{array}{l}\text { An increase in membrane } \\
\text { rigidity, over stabilized RNA, } \\
\text { and impaired protein } \\
\text { folding. }\end{array}$ & $\begin{array}{l}\text { Cold Shock Proteins } \\
\text { (Csps and Caps) }\end{array}$ & $\begin{array}{l}\text { Destabilize RNA secondary } \\
\text { structure. }\end{array}$ & $\begin{array}{l}\text { Control of post-harvest } \\
\text { fungal pathogens during } \\
\text { cold storage. }\end{array}$ & $\begin{array}{l}\text { Nakaminami et al., } \\
2006 \text {; Trevors et al., } \\
2012\end{array}$ \\
\hline & & Antifreeze proteins & Prevents ice crystalization. & $\begin{array}{l}\text { Provide freeze protection to } \\
\text { freeze sensitive strains. }\end{array}$ & $\begin{array}{l}\text { Venketesh and } \\
\text { Dayananda, 2008; } \\
\text { Wang et al., } 2017\end{array}$ \\
\hline & & $\begin{array}{l}\text { Membrane } \\
\text { Composition } \\
\text { (unsaturated fatty acids) }\end{array}$ & Enhances membrane fluidity. & $\begin{array}{l}\text { Provide freeze protection to } \\
\text { freeze sensitive strains. }\end{array}$ & $\begin{array}{l}\text { Heipieper et al., 2003; } \\
\text { Shivaji and Prakash, } \\
2010\end{array}$ \\
\hline \multirow[t]{3}{*}{ General } & $\begin{array}{l}\text { General stress response } \\
\text { can be triggered by many } \\
\text { stressors including } \\
\text { desiccation, heat, or cold. }\end{array}$ & $\begin{array}{l}\text { Viable but } \\
\text { Non-culturable State }\end{array}$ & $\begin{array}{l}\text { Low metabolic activity for } \\
\text { survival. }\end{array}$ & $\begin{array}{l}\text { Inaccurate enumeration of } \\
\text { viable cells. }\end{array}$ & $\begin{array}{l}\text { Lowder et al., 2000; } \\
\text { Ayrapetyan et al., } 2018\end{array}$ \\
\hline & & Polyphosphate & $\begin{array}{l}\text { Energy storage and stress } \\
\text { regulation. }\end{array}$ & $\begin{array}{l}\text { Resistance to } \\
\text { nutrient-limiting conditions } \\
\text { and elevated temperatures } \\
\text { in soil environments. }\end{array}$ & $\begin{array}{l}\text { Nikel et al., 2013; Gray } \\
\text { and Jakob, } 2014\end{array}$ \\
\hline & & Stringent Response & $\begin{array}{l}\text { Regulates expression of stress } \\
\text { response. }\end{array}$ & $\begin{array}{l}\text { Stress induced tolerance to } \\
\text { formulation. }\end{array}$ & Traxler et al., 2008 \\
\hline
\end{tabular}

conditions. Alginate production during water limiting stress in P. putida strain mt-2 resulted in taller biofilms covering less surface area with a thicker EPS layer compared to the $\operatorname{alg} D$ mutant strain (Chang et al., 2007). Alginate deficiency was shown to decrease stress tolerance in biocontrol and plant growth promoting strains of $P$. putida and P. fluorescens (Svenningsen et al., 2018; Marshall et al., 2019).

Several more polysaccharides are capable of supporting Pseudomonas sp. biofilm integrity including levan and the polysaccharide synthesis locus (psl) dependent polysaccharide. Levan has been hypothesized as a source of nutrient stores to protect cells within the biofilm from starvation (Mann and Wozniak, 2012). Studies of $P$. syringae biofilm formation demonstrated an increase in the levan forming enzyme, levansucrase, during planktonic exponential growth and storage of levan in cell-depleted voids within microcolonies (Laue et al., 2006). The psl-dependent polysaccharide consists of a repeating pentasaccharide containing D-mannose, D-glucose, and L-rhamnose (Byrd et al., 2009). The deletion of psl genes has been demonstrated to dramatically decrease biofilm formation in $P$. aeruginosa (Ma et al., 2012). In addition, the comparison of alginate or Psl producing strains revealed that overproduction of alginate leads to mucoid biofilms, which occupy more space, while Psl-dependent biofilms are densely packed.

\section{Biofilm Disruption of Formulation Methods}

Detrimental biofilms have become a major problem in healthcare, food, and agricultural industries. The resilience of biofilms to 


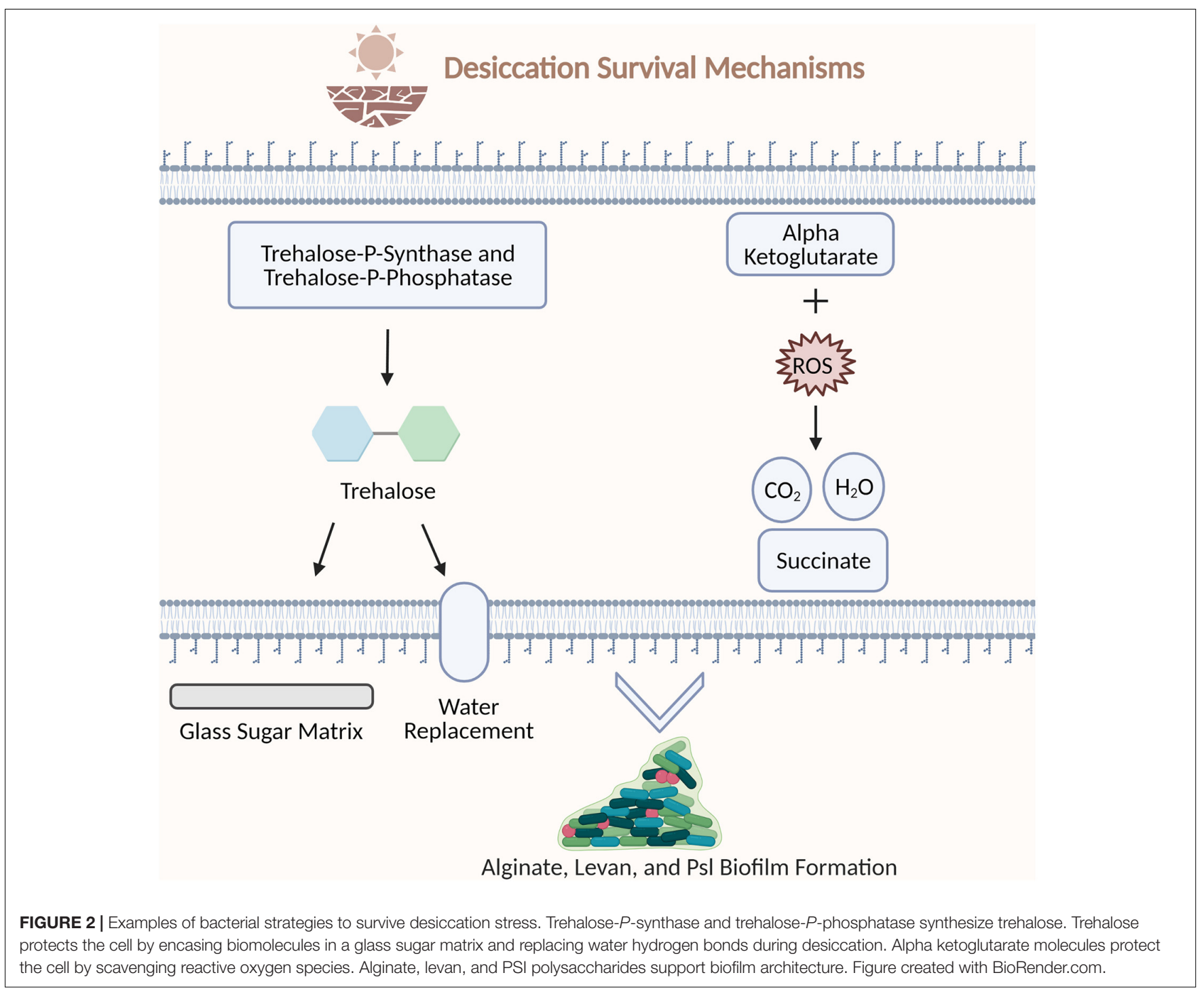

stress has led to significant issues with contaminants persisting through sterilization procedures. $P$. aeruginosa has caused persistent infections in immunocompromised patients through biofilm formation on medical equipment (Hadi et al., 2009). $P$. syringae has been isolated from irrigation water and epilithic biofilms (Morris et al., 2008). Biofilms can become the source of infection in agricultural fields by contaminating irrigation systems with plant pathogens (Raudales et al., 2014). In addition, biofilms can build up in pipes, tubing, and tanks causing persistent contamination during the fermentation and processing of microbial products (Rich et al., 2015). Many strategies including chelating agents, peptide antibiotics, lantibiotics and synthetic chemical compounds have been developed to control biofilms in industrial processing (Roy et al., 2018).

\section{Alginate Encapsulation}

Biological control agents can be encapsulated by surrounding the bacteria with coats of material such as polymers to create small capsules (Huq et al., 2013). Encapsulation can be used to protect biological control agents from stress and slowly release the bacteria over longer periods of time. Alginate is a common material for encapsulation because it is biodegradable, non-toxic, and easy to handle (Power et al., 2011). Several $P$. fluorescens strains have been encapsulated with alginate formulations to study the impact on storage survival and pathogen control (Pour et al., 2019; Kadmiri et al., 2020). P. fluorescens strains VUPF5 and T17-4 were encapsulated with an alginate-gelatin formulation which improved shelf life and control of dry rot induced by Fusarium solani under greenhouse conditions (Pour et al., 2019). The microbial fertilizer $P$. fluorescens Ms-01 was encapsulated with halloysite and alginate or montmorillonite and alginate formulations (Kadmiri et al., 2020). Both formulations were able to preserve bacterial survival after 3 months storage at room temperature or $4^{\circ} \mathrm{C}$. Encapsulation of microorganisms in a semipermeable membrane separates and protects the cells from the surrounding environment (Pour et al., 2019). This method protects biological control agents from abiotic stresses allowing 
proliferation in the environment and effective deployment against plant pathogens.

\section{HEAT STRESS}

Bacteria are exposed to heat stress in the natural environment through various events including changes in weather and host responses. Pseudomonas species are typically mesophiles growing from a range of $20-45^{\circ} \mathrm{C}$, but there have been a few instances of thermotolerant species such as $P$. thermotolerans (Manaia and Moore, 2002). The opportunistic pathogen $P$. aeruginosa can infect immunocompromised individuals and has been isolated from patients experiencing fevers over $38^{\circ} \mathrm{C}$ (Han et al., 2019). Pseudomonas strains have been discovered all over the world including areas on the equator with elevated temperatures (Fernandes et al., 2018; Eheth et al., 2019).

With advancements in food safety and other fields of research, bacteria are exposed to extreme temperatures during the manufacturing of products. Heat treatments involved in pasteurization and sterilization have widely been used for food safety (Cebrián et al., 2017). Several Pseudomonas species including $P$. lundensis and $P$. fragi have heat-resistant proteases responsible for the spoilage of dairy products (Marchand et al., 2009; Stoeckel et al., 2016). Similarly, beneficial bacteria are exposed to heat during the formulation process to create an easily distributed and shelf-stable dried product. During this process bacteria could be spray dried at temperatures above $100^{\circ} \mathrm{C}$, but there are less harsh options available such as freeze drying that may be more suitable for temperature sensitive strains (Anekella and Orsat, 2013).

Heat stress affects many critical bacterial structures including the membrane, DNA, and proteins. Damage to lipopolysaccharides compromises outer and cytoplasmic membrane structures resulting in blebbing, meaning protrusions of the outer membrane, and a loss of permeability (Russell, 2003). The loss of permeability can lead to a leakage of intracellular compounds and an inability to transport substances into the cell. DNA can be impacted from heat exposure by an increase in mutation frequency and both single and double stranded DNA breaks (Cebrián et al., 2017). Protein denaturation is another potentially lethal effect of heat stress leaving structural proteins and enzymes damaged. Pseudomonas strains have evolved to rapidly respond to the harsh effects of heat stress through production of chaperones and proteases, and regulating with thermosensors and alternative sigma factors (Figure 3).

\section{Chaperone Overview}

Bacteria must make rapid responses to the changing environment by forming and replacing cellular proteins. Molecular chaperones are proteins that play a critical role in this process by assisting with the correct folding and assembly or disassembly of other proteins (Lawless and Hubbard, 2014). Chaperones remain important under non-stressed conditions as self-assembly of some proteins occur at slower rates and can lead to misfolding or aggregation of partially folded intermediates (Alix, 2006). A rapid increase in chaperone synthesis occurs under heat

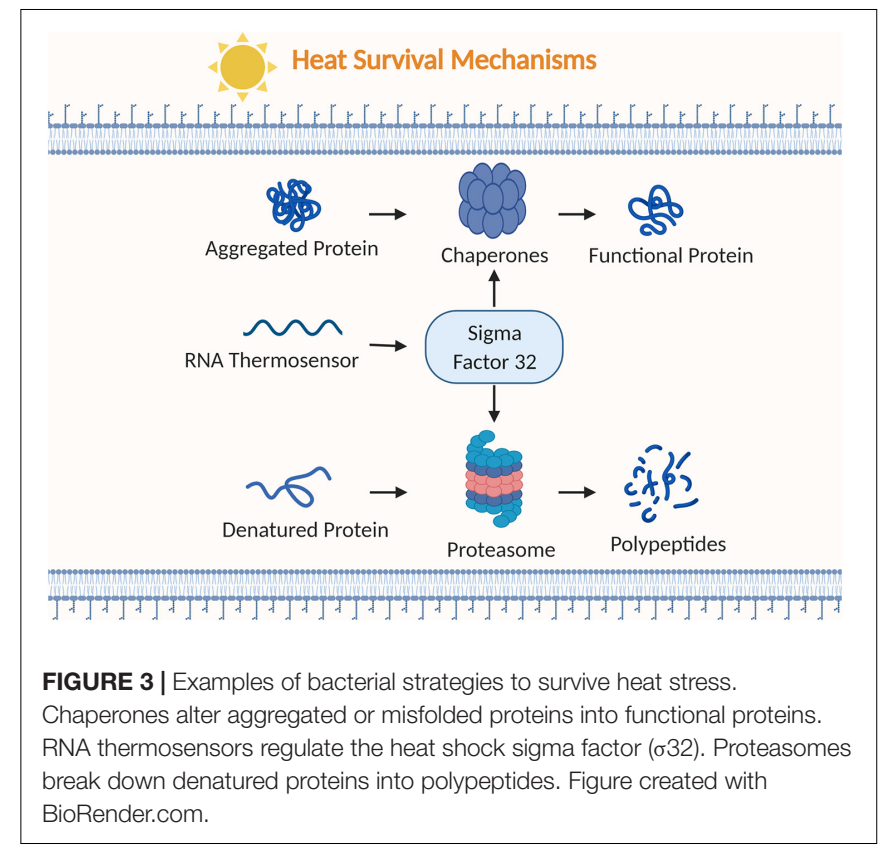

and other stress conditions to control the aggregation of denatured proteins.

\section{Chaperone - GroEL/GroES}

GroEL and DnaK are two well characterized chaperone systems conserved throughout many bacteria (Singh and Gupta, 2009). The heat shock protein system GroEL/GroES consists of the $60 \mathrm{kDa}$ chaperonin GroEL that forms two stacked rings in a barrel-like structure and a $10 \mathrm{kDa}$ cofactor GroES that forms a single ring structure (Alix, 2006). An unfolded protein binds to the hydrophobic amino acid residues on the interior rim of the GroEL ring opening (Georgescauld et al., 2014). ATP binds to GroEL inducing a conformational change allowing GroES to attach and close off GroEL. This formation results in an enclosed cage with a hydrophilic interior leading the unfolded protein to release from the rim and refold. ATP hydrolysis and protein binding to the opposite ring causes GroES and the protein to release.

Research on heat shock response in Pseudomonas has revealed a GroEL/GroES system similar to the system found in the model organism E. coli (Ito et al., 2014). The GroES/GroEL system was found in $P$. aeruginosa PAO1 through S1 nuclease mapping and northern hybridization with a two-fold upregulation under heat shock (Fujita et al., 1998). The groES and groEL region is conserved amongst Pseudomonas species. In fact, the $536 \mathrm{bp}$ region of the groE gene was used to develop a diagnostic PCR assay for detection of $P$. aeruginosa, $P$. putida, $P$. fluorescens, and P. stutzeri (Clarke et al., 2003).

\section{Chaperone - DnaK/DnaJ/GrpE System}

The DnaK, DnaJ, and GrpE chaperone system prevents proteins that are damaged or stuck in an intermediate folded state from aggregating. The system consists of the chaperone DnaK, the co-chaperone DnaJ, and the nucleotide exchange factor GrpE. 
DnaK is a $70 \mathrm{kDa}$ chaperone with an ATP-binding N-terminal, a substrate binding domain, and a peptide binding C-terminal domain (Mayer et al., 2000). The hydrophobic amino acid residue of misfolded proteins will bind to the substrate binding domain of DnaK. DnaJ will promote hydrolysis of ATP to ADP at the $\mathrm{N}$-terminal ATPase domain (Alderson et al., 2016). When ADP is bound, the C-terminal domain locks down on the protein by closing off the substrate-binding site. DnaJ dissociates and the complex will continue to hold the protein. GrpE binds leading to a conformational change that releases ADP and shifts DnaK to an open conformation.

Several studies have been conducted to better understand the role of DnaK in the Pseudomonas heat shock response. Transcriptome analysis was performed on $P$. aeruginosa PAO1 grown at human body temperature $\left(37^{\circ} \mathrm{C}\right)$ and an elevated temperature $\left(46^{\circ} \mathrm{C}\right)$ (Chan et al., 2016). RNA sequencing revealed 133 genes were differentially expressed including the upregulation of dnaK, dnaJ, and groEL at $46^{\circ} \mathrm{C}$ compared to human body temperature. The heat shock response of $P$. putida KT2442 was elucidated by constructing and testing null mutants of molecular chaperone genes (Ito et al., 2014). The P. putida KT2442 dnaJ mutant was temperature-sensitive and formed more protein aggregates in response to heat stress compared to the wild type.

\section{Protease Overview}

Proteases are crucial for rapid responses to environmental changes when damaged proteins cannot be salvaged by chaperones or other heat shock proteins. Proteases are enzymes that catalyze the breakdown of proteins into amino acids or smaller polypeptides by cleaving peptide bonds. They contribute to the heat shock response by removing misfolded or damaged proteins and recovering the amino acids (Meyer and Baker, 2011). Proteases will also degrade functional proteins such as sigma factors, metabolic enzymes and structural proteins that are no longer needed as cells adapt to changes (Kirstein et al., 2009; Bittner et al., 2016). The Clp protease family is a highly conserved system that is vital for stress survival in many bacteria, including Pseudomonas species.

Clp complexes contain chaperones and proteases that belong to the heat shock protein family HSP100 and the ATPases Associated with diverse cellular Activities (AAA+) protein superfamily. The AAA+ superfamily has a highly conserved AAA + module consisting of 250 amino acids, and they typically have motifs involved in ATP binding and hydrolysis (Ogura and Wilkinson, 2001). ATP-dependent Clp protease (ClpP) consists of a ClpP serine peptidase subunit and a AAA+ ATPase subunit such as ClpA, ClpC, or ClpX (Richter et al., 2010). ClpP forms a barrel-like structure with two stacked heptameric rings of the $\mathrm{ClpP}$ serine peptidase subunit and is enclosed by one or two hexameric rings of the AAA + ATPase subunit. The Clp ATPase subunit uses ATP hydrolysis to unfold protein substrates then directs them through a central pore to the proteolytic chamber of ClpP for degradation (Snider et al., 2008).

Clp Peptidase has been found to control diverse aspects of cellular physiology in Pseudomonas species. The proteolysis activity of ClpP helps regulate the stress response sigma factor RpoS ( $\sigma 38)$ and other transcriptional regulators influencing many factors including motility, surface attachment, and antimicrobial activity (Bruijn and Raaijmakers, 2009). $P$. aeruginosa was found to have a second ClpP isomer which impacts stationary-phase cells, microcolony organization and biofilm formation (Hall et al., 2017). ClpP, clpX, and $c l p P 2$ null mutants of $P$. aeruginosa PAO581 were created to study the regulation of exopolysaccharide alginate overproduction and the conversion to a mucoid phenotype which are markers for the onset of chronic lung infection in cystic fibrosis patients (Qiu et al., 2008). All null mutants demonstrated a decrease in transcriptional activity of the extracytoplasmic function sigma factor AlgU which is responsible for alginate overproduction. The $c l p P$ and $c l p X$ null mutants were unable to maintain the mucoid phenotype.

\section{Regulation by Chaperones and Proteases}

Chaperones and Proteases such as DnaK and Clp control the regulation of cyclic lipopeptides in many Pseudomonas species. Cyclic lipopeptides have a role in biofilm formation, surface motility, and antimicrobial activity (Dubern et al., 2005). Putisolvin and massetolide have activity against oomycete plant pathogens by causing lysis of zoospores (Raaijmakers et al., 2010). The DnaK complex is hypothesized to regulate putisolvin biosynthesis by controlling activity of other regulators or assisting with the assembly of putisolvin peptide synthetases. ClpP regulates massetolide biosynthesis by degradation of putative transcriptional repressors of massetolide biosynthesis genes (Bruijn and Raaijmakers, 2009). A range of growth temperatures $\left(32,28,21,16\right.$, and $\left.11^{\circ} \mathrm{C}\right)$ were tested on a P. Putida strain and three dnaK, dnaJ, and grpE mutants to determine the effect on putisolvin production (Dubern et al., 2005). It was shown that putisolvin production decreased at high growth temperatures, but putisolvin production increased at low temperatures. DnaK and DnaJ are required to produce putisolvins at low temperatures. These studies indicate that growth temperature can influence DnaK and DnaJ regulation of putisolvin synthesis, and growth at low temperatures may enhance putisolvin production. Chaperones and proteases are key components to survival and efficacy for many Pseudomonas species. Understanding regulatory effects of these proteins is crucial to the development of Pseudomonas strains as biocontrol products.

\section{Thermosensors}

Adverse environmental conditions such as elevated temperatures can damage proteins requiring molecular chaperones or proteases to help repair cells. Thermosensors are RNA, DNA, or protein molecules that react to changes in environmental conditions and regulate gene expression of the heat shock response and other stress responses. Temperature shifts cause thermosensors to change their secondary structure, and this change typically either exposes or blocks nucleic acid regions influencing expression of a gene. DNA topology can act as a stress sensor because transcription efficiency is sensitive to changes in DNA supercoiling (Klinkert and Narberhaus, 2009). RNA 
thermosensors are translational control elements that are mostly located in the $5^{\prime}$ untranslated region (UTR) of messenger RNA encoding heat shock proteins (Narberhaus, 2010). There are a diverse set of protein thermosensors including transcriptional repressors, sensor kinases, chaperones, and proteases (Collin and Schuch(eds), 2009). The diversity is due to the sensitivity of tertiary and quaternary protein structures to temperature stress (Klinkert and Narberhaus, 2009).

Repression of heat shock gene expression (ROSE) elements are RNA thermosensors located in the 5' UTR of some heat shock protein mRNA (Nocker et al., 2001). ROSE elements structures consist of two to four stem loops and they are characterized by a conserved $G$ residue that pairs with the Shine Dalgarno sequence (AGGA) (Klinkert and Narberhaus, 2009). Under normal conditions, the conserved $G$ residue opposite the Shine Dalgarno sequence closes the loop by a weak GG base pair preventing gene expression. The weak GG base pair breaks under temperature stress allowing the ribosome binding site to be accessed for translation.

Structural and functional analysis has uncovered the ROSE elements' role in heat shock and virulence regulation for Pseudomonas species. P. putida and P. aeruginosa contain a simpler ROSE element with only two hairpins compared to previously discovered Rhizobium sp. ROSE structures with three to four hairpin structures (Nocker et al., 2001; Krajewski et al., 2013). The ROSE element precedes an ibpA gene which encodes the small heat shock protein IbpA (inclusion body associated protein A). High sequence conservation of $i b p A$ untranslated regions suggests ROSE thermosensors could be common for IbpA regulation in Pseudomonas species. ROSE elements have also been studied for the temperature induced regulation of rhamnolipid production in Pseudomonas species. Bioremediation strains of Pseudomonas produce rhamnolipids which facilitate the uptake and degradation of hydrocarbons such as crude oil in polluted environments (Chrzanowski et al., 2012). P. aeruginosa is one of the most competent rhamnolipid producers and safe methods to produce rhamnolipids are being explored including strain engineering to diminish pathogenicity (Chong and Li, 2017). P. putida KT2440 rhamnolipid production increased by more than $60 \%$ when growth temperature was increased from 30 to $37^{\circ} \mathrm{C}$ (Noll et al., 2019). These studies demonstrate the potential to design a process for rhamnolipid production linked to temperature and ROSE regulation.

\section{RNA Polymerase Sigma Factors}

Sigma factors are essential for regulation of both essential genes and conditional responses such as heat or cold shock. A sigma factor is a protein required for transcription initiation that allows RNA polymerase to bind to specific gene promoters. Primary sigma factor $(\sigma 70)$ is named for its $70 \mathrm{kDa}$ molecular weight, and it is responsible for regulation of essential genes during exponential growth. Sigma factor 70 binds to RNA polymerase allowing promoter recognition at -10 and -35 nucleotides upstream of the start site (Potvin et al., 2008). Alternative sigma factors are needed for transcription of genes linked to environmental or physiological changes. In response to stress RNA polymerases are redirected by alternative sigma factors to activate transcription of genes to help the cell respond to new conditions.

Genome analysis of $P$. aeruginosa $\mathrm{PAO} 1$ and $P$. syringae $\mathrm{pv}$. syringae B728a revealed the presence of 24 and 15 putative sigma factors, respectively, including primary sigma factor $(\sigma 70)$, heat shock sigma factor $(\sigma 32)$, stationary phase sigma factor $(\sigma 38)$, and nitrogen-limitation sigma factor ( $\sigma 54)$ (Potvin et al., 2008; Thakur et al., 2013). The majority were classified as extracytoplasmic function (ECF) sigma factors which are involved in the regulation of a diverse set of functions including iron starvation, cell envelope stress, solvent tolerance, and oxidative stress (Otero-Asman et al., 2019). Stationary phase sigma factor RpoS ( $\sigma 38$ ) is a master stress response regulator active during stationary phase to protect against heat shock, starvation, and osmotic shock (Schuster et al., 2004). The heat shock sigma factor $\mathrm{RpoH}(\sigma 32)$ was upregulated as temperature increased from 30 to $42^{\circ} \mathrm{C}$ in $P$. aeruginosa (Nakahigashi et al., 1998). RpoH regulates heat shock genes responsible for the expression of chaperones and proteases such as GroEL, GroES, DnaK, DnaJ, GrpE, and ClpP (Aramaki et al., 2001; Potvin et al., 2008). Sigma Factor AlgU ( $\sigma 22)$ mutant strains of Pseudomonas fluorescens CHA0 were studied to determine the impact of AlgU on environmental stress survival (Schnider-Keel et al., 2001). Schnider-Keel et al. (2001) found that AlgU is critical for survival against desiccation and hyperosmolarity in soil environments. Alternative sigma factors are critical to survival against major industrial and environmental stresses.

\section{COLD STRESS}

Cold climates are widespread on earth, with ice covering $10 \%$ of the earth's surface and a large percentage of the biosphere existing at temperatures below $15^{\circ} \mathrm{C}$ (Kuhn, 2012). Bacteria that can colonize these extreme environments and grow at $-20^{\circ} \mathrm{C}$ to $20^{\circ} \mathrm{C}$ are called psychrophiles (De Maayer et al., 2014). Several Pseudomonas psychrophiles have been isolated from glaciers in Antarctica and the Arctic Circle such as P. antarctica (Villeret et al., 1997; Dziewit et al., 2013; Lee et al., 2017). Cold stress survival is of particular importance for the control of postharvest fruit and vegetable diseases. Many Pseudomonas species are adapted to cold stress and effectively control post-harvest fungal pathogens during cold storage (Wallace et al., 2017; Aiello et al., 2019). The strain $P$. syringae ESC-10 was able to survive 30 days of $2^{\circ} \mathrm{C}$ cold storage and prevented post-harvest blue mold on apples (Errampalli and Brubacher, 2006). Many strains of Pseudomonas, such as P. syringae ESC-10, are psychrotrophs or mesophiles that grow at more moderate temperatures and have adapted mechanisms to survive exposure to cold stress.

Freezing cultures, using processes such as freeze drying, is one of the most common methods for preserving bacterial inoculants. Freeze drying is a freezing and dehydration preservation technique that involves freezing, lowering pressure and removing ice through sublimation (Fellows, 2009). The food industry and the pharmaceutical industry rely on freeze drying for starter cultures, drug delivery, and long-term storage in culture collections. Manufacturing of commercial foods requires vast 


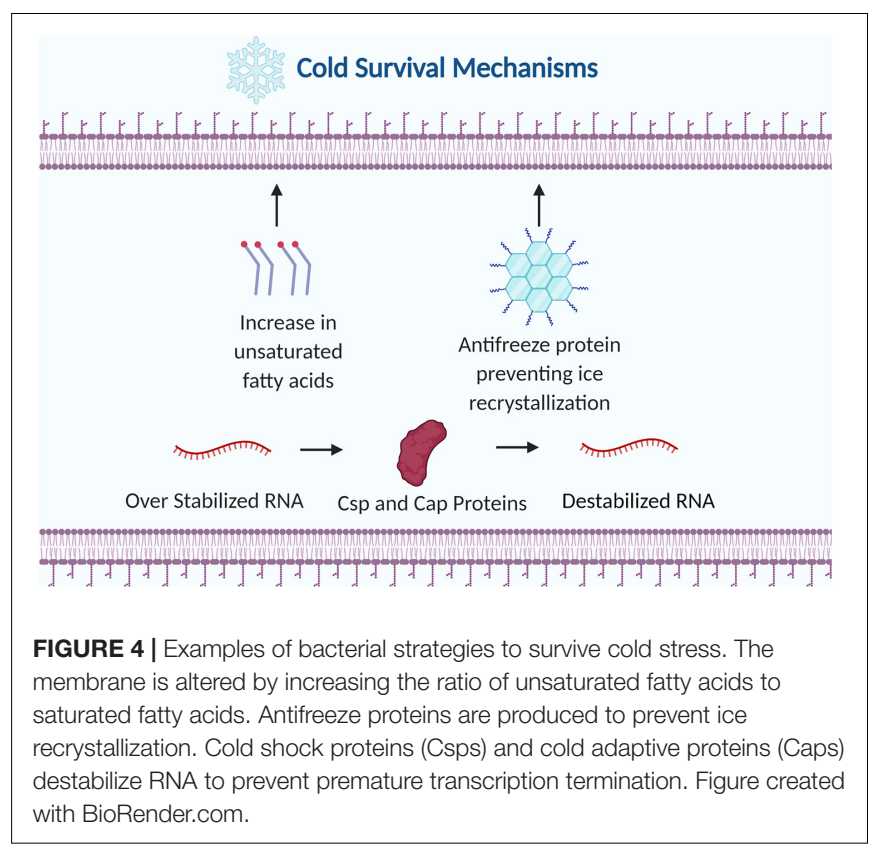

amounts of starter cultures with cheese production alone requiring approximately one billion liters of bulk starter per year (Champagne et al., 1991). Freeze drying of biocontrol Pseudomonas strains has been explored as a method to deliver viable cells for crop protection (Cabrefiga et al., 2014).

Cold stress drastically affects cellular physiology by damaging the cell membrane, impairing protein folding and hindering transcription and translation (Kumar et al., 2020). Rapid chilling can induce phase separation of phospholipids within the lipid bilayer leading to membrane permeability and consequently cell death (Cao-Hoang et al., 2008). At low temperatures the secondary structures of RNA stabilizes which slows down transcription elongation and ribosomal movement on RNA (Phadtare and Inouye, 2004). Cold tolerant microbes can survive these harsh conditions by adjusting the fatty acid composition in the membrane, producing specialized enzymes that are active at low temperatures, and by creating cryoprotective biomolecules (Figure 4).

\section{Cold Shock Proteins and Cold Acclimation Proteins}

Cold shock proteins (csp) and cold acclimation proteins (cap) are two strategies Pseudomonas strains utilize to adapt to cold environments. Genes encoding cold shock proteins are expressed immediately after cold shock while genes encoding cold acclimation proteins are expressed during prolonged exposure to low temperatures (Trevors et al., 2012). Cold shock proteins are transcriptional anti-terminators or translational enhancers that destabilize RNA secondary structure at low temperatures (Nakaminami et al., 2006). This destabilization of RNA secondary structure prevents premature transcription termination during cold shock. Cold acclimation proteins have been found to have a high level of amino acid sequence identity to members of the CspA family of E. coli and the homologous proteins of other microorganisms (Berger et al., 1997). CapA contained highly conserved ribonucleoprotein (RNP1 and RNP2) involved with binding to single stranded DNA and RNA, suggesting similar functionality to Csp proteins.

The expression level of a cold shock protein from $P$. fluorescens MTCC 103 (MW $14 \mathrm{kd}$ ) and a cold resistant protein (MW $35 \mathrm{kd}$ ) from the $P$. fluorescens mutant CRPF8 were studied over a range of temperatures from $37^{\circ} \mathrm{C}$ down to $4^{\circ} \mathrm{C}$ (Khan et al., 2003). Expression of the cold shock protein and the cold resistant protein increased in response to decreased temperature with the rate of induction of protein synthesis reaching its maximum at $10^{\circ} \mathrm{C}$. Eighteen Pseudomonas strains isolated from Antarctica were analyzed for the presence of cold shock proteins and cold accumulation proteins (Panicker et al., 2010). CapB was present in all Antarctic Pseudomonas isolates, but CspA was absent. The survival of these isolates in the perennially cold Antarctic environment could be attributed to the continuous expression of $\mathrm{CapB}$ and its regulatory role in transcription and translation of essential genes.

\section{Antifreeze Proteins}

Antifreeze proteins also called ice structuring proteins are icebinding proteins produced by certain organisms to enhance survival in freezing temperatures. Antifreeze proteins inhibit the spread of ice by lowering the freezing point and preventing ice recrystallization (Venketesh and Dayananda, 2008). Antifreeze activity is theorized to occur by an adsorption inhibition mechanism where antifreeze proteins bind to ice crystals and curved ice structures form between the antifreeze proteins. Due to the Kelvin effect, the curved surface is energetically less favorable than flat surfaces which prevents additional water molecules from joining the ice formation (Wang et al., 2017). Ice recrystallization, where ice crystals gradually grow larger in size at the expense of smaller ice crystals, is a lethal stress for cells in frozen conditions. Antifreeze proteins can prevent recrystallization by inhibiting water molecules from leaving ice crystals or by acting as a surfactant to reduce surface tension.

The freezing resistance of antifreeze proteins was discovered in several cold dwelling Pseudomonas species including strains of P. ficuserectae, P. fluorescens, and P. putida (Kawahara et al., 2004; Singh et al., 2014; Cid et al., 2016). Freeze sensitive mutants and a freeze resistant wild type strain of the plant growthpromoting rhizobacterium $P$. putida GR12-2 were tested for the ability to secrete antifreeze proteins (Kawahara et al., 2001). The freeze sensitive mutants secreted a much lower concentration of antifreeze protein compared to the wild type. Freeze resistance could be partially restored by adding purified antifreeze proteins to the freeze sensitive mutant's cell suspension. The antifreeze gene afpA from $P$. putida GR12-2 was cloned into E. coli yielding a $72 \mathrm{kDa}$ protein that exhibited low levels of antifreeze and ice nucleation activities compared to the native protein (Muryoi et al., 2004). The recombinant protein may not have been properly post translationally modified with previous work indicating the carbohydrate lipoglycoprotein was required for ice nucleation activity. These studies demonstrate the potential of accumulated antifreeze proteins to inhibit ice formation in both freeze resistant and freeze sensitive strains. 


\section{Membrane Composition}

Altering membrane composition is a critical strategy to combat the rigidity of the cell membrane during cold shock. Membrane fluidity is maintained by increasing the ratio of unsaturated fatty acids to saturated fatty acids or by altering the levels of anteiso branched chain fatty acids in membrane phospholipids (Shivaji and Prakash, 2010). Rigidity of the membrane signals the adjustment to membrane lipid composition through biosynthetic pathways including FabAB and Des mediated pathways. The cis configuration of unsaturated fatty acids has double bonds which produce a bend in the fatty acid chain (Heipieper et al., 2003). These bends create more space between the unsaturated fatty acid chains producing a more flexible and fluid membrane during cold stress.

The synthesis of unsaturated fatty acids by fatty acid desaturase enzymes is essential for the survival of Pseudomonas during cold stress. The cold tolerant strains Pseudomonas sp. AMS8 and Pseudomonas sp. A3 were found to produce large amounts of monounsaturated fatty acids at low temperatures (Garba et al., 2016, 2018). $\Delta 9$ - fatty acid desaturase genes were isolated from each of the strains and were subsequently cloned and successfully expressed in E. coli. In both studies the recombinant $E$. coli had a functional putative $\Delta 9$-fatty acid desaturase capable of increasing the total amount of cellular unsaturated fatty acids. Functional genomics was used to study the cold stress response in the bacterial model organism P. putida KT2440 (Frank et al., 2011). Transcriptome sequencing and proteome peptide profiling of KT2440 revealed that the degradation pathway of valine to branched-chain fatty acids ( $b k d$ operon) was upregulated during growth at low temperatures. These studies illustrate the importance of homeoviscous adaptation to support membrane fluidity during cold stress.

\section{GENERAL STRESS RESPONSE}

The general stress response is vital to survival in nature when bacteria are challenged with a multitude of different stresses. In the environment bacteria must overcome many stresses including nutrient limitation, desiccation, temperature extremes, and UV irradiation. While targeted stress responses typically help bacteria overcome a specific stress, the general stress response provides resistance against a diverse set of stresses (Storz and Hengge, 2011). General stress response provides cross-protection where defense against one stress can lead to enhanced tolerance to other stresses. This primes the cell for survival against other imminent stresses. The general stress response of Pseudomonas species includes transformation into the viable but non-culturable state, storage of polyphosphate, and induction of the stringent response (Figure 5; Storz and Hengge, 2011).

\section{Viable but Non-culturable State}

Viable but non-culturable (VBNC) cells have low metabolic activity and intact membranes, but they are unable to replicate until they enter a more hospitable environment (Ayrapetyan et al., 2018). Pseudomonas strains can enter this state as a response to unfavorable environmental conditions such as nutrient

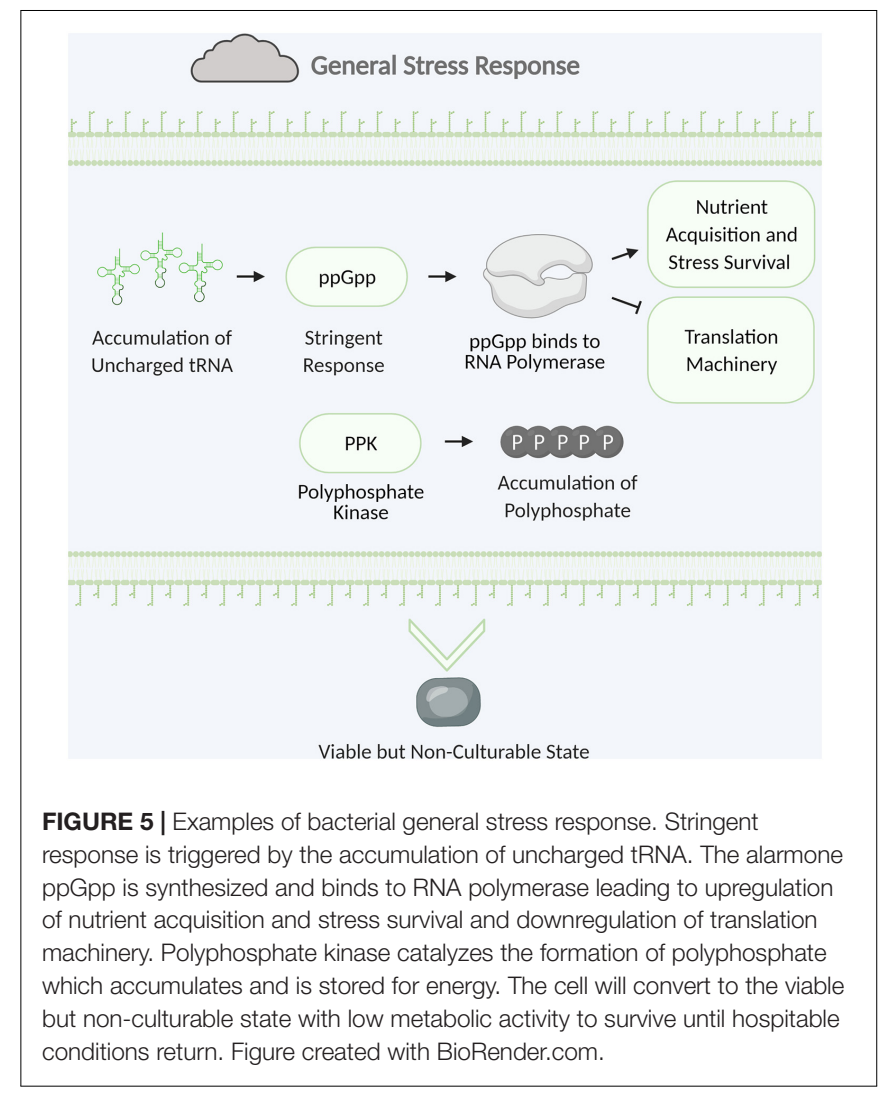

limitation, temperature extremes, and desiccation (Lowder et al., 2000; Arana et al., 2010; Pazos-Rojas et al., 2019). Resuscitation methods that allow VBNC cells to repair and transition into a culturable state can vary greatly depending on the type of microorganism and environmental conditions (Bédard et al., 2014). The plant growth-promoting rhizobacterium $P$. putida KT2440 was found to return to a cultivable state after interaction with maize root exudates or a $48 \mathrm{~h}$ rehydration in water (PazosRojas et al., 2019). The persistence of VBNC Pseudomonas in the natural environment was demonstrated with the biocontrol strain $P$. protegens $\mathrm{CHA} 0$ which survived in an uncovered field plot as a combination of dormant and VBNC cells for 72 days (Troxler et al., 2012).

Studies were conducted by Pazos-Rojas et al. (2019) to determine the survival of $P$. putida KT2440 exposed to desiccation stress. P. putida KT2440 was subjected to 18 days of desiccation then rehydrated with either maize root exudates for a short time or water for $48 \mathrm{~h}$ (Pazos-Rojas et al., 2019). Live/dead staining showed that bacterial counts for desiccated and rehydrated cells were just as high as the counts for the bacteria that did not get exposed to stress. Cells exposed to desiccation stress that were neither rehydrated nor protected with trehalose stained red indicating death or a compromised membrane. The presence of VBNC cells after desiccation exposure was tested again with a GFP-tagged $P$. putida strain which exhibited active GFP expression and housekeeping gene expression was confirmed with RT-PCR. A cytokine secreted by Micrococcus luteus called resuscitation-promoting factor (Rpf) 
has been discovered which enables the resuscitation of VBNC cells in a wide range of Gram negative and Gram positive bacteria (Su et al., 2013). There is limited information on potential homologous genes in Pseudomonas, but tests could be conducted to determine if adding Rpf to VBNC Pseudomonas cells improves resuscitation.

\section{Biocontrol Viability Requirements}

Biological control agents have a viability standard which is listed on the product label. The company manufacturing the product determines the standard based on product efficacy and typically guarantees a minimum colony-forming unit (CFU) per gram (Cabrefiga et al., 2014; Anderson et al., 2018). The stress of manufacturing live microbial products can lead a fraction of the population to enter a VBNC state (Davis, 2014). VBNC cells can return to a culturable state in more hospitable environmental conditions or by resuscitating microbes through a rehydration process. A large population of VBNC cells which are more difficult to enumerate using traditional plating methods can complicate the process of ensuring the product meets the viability requirements on the label. Two methods to identify culturable and VBNC cells are live/dead staining with microscopic enumeration or detecting housekeeping gene expression by reverse transcription polymerase chain reaction (Li et al., 2014). Understanding the requirements for different metabolic states and improving enumeration techniques are both essential for enabling more accurate viability standards.

\section{Polyphosphate}

Polyphosphate is a polymer containing a few to several hundred phosphate residues linked by high energy phosphoanhydride bonds (Brown et al., 2004). Many bacteria can intracellularly synthesize and degrade polyphosphate with polyphosphate kinases and exopolyphosphatase. Microorganisms accumulate polyphosphate to store energy, and this energy is released by ATP hydrolysis. Polyphosphate is also involved in stress responses including regulation of the stringent response, induction of the stress response sigma factor, and biofilm formation (Nikel et al., 2013; Gray and Jakob, 2014).

The role of polyphosphate was examined with Pseudomonas sp. B4 and P. fluorescens Pf0-1 polyphosphate kinase deficient mutants. Comparative proteomics on the Pseudomonas sp. B4 mutant revealed energy metabolism and nucleoside triphosphate formation were negatively impacted leading to an increase in energy generating metabolic pathways including oxidative phosphorylation and the tricarboxylic acid cycle (Varela et al., 2010). The P. fluorescens Pf0-1 mutant was 10-fold less competitive compared to the wild type strain in sterile soil low in inorganic phosphate, and it had an increased sensitivity to elevated temperatures in sterile soil (Silby et al., 2009). These studies demonstrate the importance of polyphosphate in energy storage and stress response for Pseudomonas species.

\section{Stringent Response}

Stringent response is a bacterial survival strategy using tRNAs as a sensor to overcome different stressors including nutrient starvation, iron limitation, and heat shock (Vinella et al., 2005;
Pletzer et al., 2016). Gene expression switches from growth promotion to survival during stationary phase when nutrients are scarce. The lack of available amino acids leads to an accumulation of ribosomal bound uncharged tRNAs. Binding of uncharged tRNA to the ribosome causes ribosome stalling which triggers RelA synthetase to convert Guanosine-5('-triphosphate (GTP) into the alarmone guanosine tetraphosphate (ppGpp) (Traxler et al., 2008). SpoT also regulates the stringent response by modifying ppGpp concentration through hydrolysis of ppGpp to guanosine diphosphate (GDP) and pyrophosphate (Boes et al., 2008). ppGpp binds RNA polymerase which halts so that the synthesis of translation machinery (such as ribosomal proteins, rRNA, and tRNA) is decreased, whereas transcription of genes involved in nutrient acquisition, amino acid biosynthesis and stress survival is increased (Wu et al., 2020).

Stringent response is a major factor in stress survival and virulence in both medically and biotechnologically relevant Pseudomonas strains. $P$. aeruginosa and $P$. putida stringent response mutants ( $\triangle$ relA $\Delta s p o T$ ) were created to test the influence of the stringent response on antioxidant defenses, antibiotic tolerance, biofilm formation, and quorum-sensing (Khakimova et al., 2013; Schafhauser et al., 2014). Studies involving a $P$. aeruginosa mutant revealed that stringent response regulates catalase activity and hydrogen peroxide tolerance during both planktonic and biofilm growth (Khakimova et al., 2013). Another study on a $P$. aeruginosa stringent response mutant showed that (p)ppGpp significantly modulates the quorum-sensing hierarchy of a family of molecules controlling antibacterial and virulence functions (Schafhauser et al., 2014). A P. putida stringent response mutant was defective in biofilm dispersal indicating that the stringent response plays a role in relaying the nutrient stress signal to the biofilm dispersal machinery (Díaz-Salazar et al., 2017).

Stringent response has been found to influence the production of secondary metabolites in agriculturally relevant Pseudomonas strains. Pseudomonas species produce antifungal compounds such as pyrrolnitrin and phenazine that inhibit fungal plant pathogens by suppressing mycelial growth (Huang et al., 2018). Stringent response mutants of the biological control agents Pseudomonas sp. strain DF41 and Pseudomonas chlororaphis PA23 were created to stop the production of (p)ppGpp (Manuel et al., 2011; Manuel et al., 2012). The P. chlororaphis PA23 relA mutant had elevated pyrrolnitrin production while phenazine (PHZ) levels remained unchanged. Both P. chlororaphis PA23 and Pseudomonas sp. strain DF41 relA mutants exhibited increased antifungal activity against the pathogen Sclerotinia sclerotiorum (Lib.) de Bary. Expression of secondary metabolites involved in antifungal activity are energetically costly and are reduced during the stringent response when nutrients are scarce (Manuel et al., 2012).

\section{Stress Induced Tolerance}

Exposure to sublethal stress is a strategy that has been used to induce the stress response and improve survival during formulation. Pseudomonas biocontrol agents have undergone hyperosmotic adaptation to improve formulation viability and 
efficacy against pathogens (Cabrefiga et al., 2014; Wang et al., 2020b). Comparative transcriptomic analysis was conducted comparing $P$. protegens SN15-2 grown under hyperosmotic conditions or normal osmotic conditions then shocked with lethal temperatures (Wang et al., 2020a). The strains were exposed to cold or heat shock from a range of $-15^{\circ} \mathrm{C}$ to $58^{\circ} \mathrm{C}$. Exposure to the hyperosmotic environment increased the cytoplasmic concentration of potassium ions, altered the composition of the cell envelope, and increased trehalose and proline synthesis. The accumulation of potassium ions could be a strategy to maintain the osmotic or turgor pressure after osmotic shock (Cagliero and Jin, 2013). Osmotic stress damaged the cell envelope due to salt-induced dehydration leading to an increase in glycerophospholipid metabolism to maintain membrane integrity (Wang et al., 2020a,b). Triggering the stress response with osmotic stress prepared P. protegens SN15-2 for exposure to other stresses such as lethal temperatures.

This strategy of preparing cells with a sublethal shock translates to industrial formulation stress. Stress adaptation by exposure to osmotic shock has been conducted on $P$. fluorescens EPS62e and $P$. protegens SN15-2 with improved viability after spray drying and fluidized-bed drying, respectively (Cabrefiga et al., 2014; Wang et al., 2020b). Intentionally triggering the stress response or targeting expression of specific survival mechanisms could enhance survival and colonization in the environment leading to better product performance. As described earlier in this review, Manuel et al. (2012) found that induction of stringent response can decrease the expression of some secondary metabolites involved in antifungal activity. When attempting this method, there needs to be an understanding of what mechanisms of survival are induced and if this will lead to a decrease in the production of the antifungal compound of interest.

\section{CONCLUSION AND FUTURE DIRECTIONS}

Pseudomonas species are subjected to stress in the natural environment and have adapted mechanisms to survive these harsh conditions. Members of the Pseudomonas genus have been studied for their importance in bioremediation, plant pathogen control, antibiotic resistance, and pathogenicity against humans (Chin-A-Woeng et al., 2003; Folkesson et al., 2012; Wasi et al., 2013). Advances in next generation sequencing and previous work establishing the stress mechanisms of model organisms has accelerated the analysis of stress mechanisms in these important organisms (Ramos et al., 2001; Vorob'eva, 2004). Desiccation, heat, and cold stress can critically impact cells through protein and nucleic acid damage, disruption of major biosynthesis pathways, and loss of membrane integrity.

Bacteria have evolved a number of processes aimed at surviving or thriving under stressful conditions. There are both universal and targeted cellular responses designed to help cells cope with a variety of different stressors. Compatible solutes and polyphosphate can be accumulated as an energy source in the cell for use under critical conditions. Biofilm and EPS production protects the cell through an increased number of persister cells and an extracellular matrix barrier. The viable but non-culturable state is a strategy to persist through harsh conditions by keeping living cells at a low rate of metabolic activity. Chaperones, proteases, thermosensors, and alternative sigma factors rapidly respond to stress by controlling protein damage and regulating stress responses. In response to low temperatures, cold shock proteins and antifreeze proteins prevent premature transcription termination and lower the freezing point, respectively. Bacterial membrane composition changes in response to temperature stress to maintain a flexible and fluid membrane. Knowledge of bacterial stress survival has led to the incorporation of bacterial protectants in the formulation of beneficial microbial products.

New techniques are being established as the knowledge of stress survival mechanisms and availability of genome sequencing are becoming more accessible. Methods demonstrated on model organisms can be applied to industrially relevant Pseudomonas strains. Two techniques that have been demonstrated on model microorganisms are selective adaptation and genetic engineering (Billi et al., 2000; Sleight and Lenski, 2007). Selective pressure has been used in laboratory settings to adapt microorganisms to stress and select for more durable phenotypes. E. coli populations were subjected to over a hundred cycles of freezing and thawing. After many generations of adaptation to this stress the fitness of the E. coli strain was improved by $90 \%$ (Sleight and Lenski, 2007). Adaptation is a tool that can be explored in more industrial relevant microorganisms although adaptation can also lead to undesirable traits. Microorganisms can be directly modified for improved resilience to abiotic stresses through genetic engineering. A sucrose-6-phosphate synthase gene from a resilient cyanobacterium was transformed into E. coli cells (Billi et al., 2000). Freeze drying, air drying, and desiccation survival was improved 10,000-fold in the transformed cells compared to the wild type cells. Studying the mechanisms of stress survival and trying new techniques to enhance survival is critical for improving beneficial applications and controlling pathogens.

\section{AUTHOR CONTRIBUTIONS}

All the authors contributed to the concept and ideas of the review, read and approved the submitted version. KC wrote the manuscript and created the figures. BJ and AG critically reviewed and revised the manuscript for publication.

\section{FUNDING}

Publication funding provided by AgBiome.

\section{ACKNOWLEDGMENTS}

The authors wish to thank the AgBiome team for their support and valuable discussions. 


\section{REFERENCES}

Aiello, D., Restuccia, C., Stefani, E., Vitale, A., and Cirvilleri, G. (2019). Postharvest biocontrol ability of Pseudomonas synxantha against Monilinia fructicola and Monilinia fructigena on stone fruit. Postharv. Biol. Technol. 149, 83-89. doi: 10.1016/j.postharvbio.2018.11.020

Alderson, T., Kim, J., and Markley, J. (2016). Dynamical structures of Hsp70 and Hsp70-Hsp40 complexes. Structure 24, 1014-1030. doi: 10.1016/j.str.2016.05. 011

Ali, S. Z., Sandhya, V., and Venkateswar Rao, L. (2013). Isolation and characterization of drought-tolerant ACC deaminase and exopolysaccharideproducing fluorescent Pseudomonas sp. Ann. Microbiol. 64, 493-502. doi: 10. 1007/s13213-013-0680-3

Alix, J. - H. (2006). "The Work of Chaperones," in Protein Synthesis and Ribosome Structure, eds K. H. Nierhaus and D. N. Wilson (New Jersey, NJ: Wiley), doi: 10.1002/3527603433.ch13

Anderson, A. J., and Kim, Y. C. (2018). Biopesticides produced by plant-probiotic Pseudomonas chlororaphis isolates. Crop Protect. 105, 62-69. doi: 10.1016/j. cropro.2017.11.009

Anderson, J. A., Staley, J., Challender, M., and Heuton, J. (2018). Safety of Pseudomonas chlororaphis as a gene source for genetically modified crops. Transgenic Res. 27, 103-113. doi: 10.1007/s11248-018-0061-6

Anekella, K., and Orsat, V. (2013). Optimization of microencapsulation of probiotics in raspberry juice by spray drying. Food Sci. Technol. 50, 17-24. doi: 10.1016/j.lwt.2012.08.003

Aramaki, H., Hirata, T., Hara, C., Fujita, M., and Sagara, Y. (2001). Transcription analysis of rpoH in Pseudomonas putida. FEMS Microbiol. Lett. 205, 165-169. doi: 10.1111/j.1574-6968.2001.tb10942.x

Arana, I., Muela, A., Orruño, M., Seco, C., Garaizabal, I., and Barcina, I. (2010). Effect of temperature and starvation upon survival strategies of Pseudomonas fluorescens CHA0: Comparison with Escherichia coli. FEMS Microbiol. Ecol. 74, 500-509. doi: 10.1111/j.1574-6941.2010.00979.x

Ayrapetyan, M., Williams, T., and Oliver, J. D. (2018). Relationship between the viable but nonculturable state and antibiotic persister cells. J. Bacteriol. 200:18. doi: 10.1128/jb.00249-18

Bashan, Y., de-Bashan, L. E., Prabhu, S. R., and Hernandez, J. (2014). Advances in plant growth-promoting bacterial inoculant technology: Formulations and practical perspectives (1998-2013). Plant Soil 378, 1-33. doi: 10.1007/s11104013-1956-X

Bédard, E., Charron, D., Lalancette, C., Déziel, E., and Prévost, M. (2014). Recovery of Pseudomonas aeruginosa culturability following copper- and chlorineinduced stress. FEMS Microbiol. Lett. 356, 226-234. doi: 10.1111/1574-6968. 12494

Berger, F., Normand, P., and Potier, P. (1997). capA, a cspA-like gene that encodes a cold acclimation protein in the psychrotrophic bacterium arthrobacter globiformis SI55. J. Bacteriol. 179, 5670-5676. doi: 10.1128/JB.179.18.56705676.1997

Berninger, T., González López, Ó, Bejarano, A., Preininger, C., and Sessitsch, A. (2018). Maintenance and assessment of cell viability in formulation of nonsporulating bacterial inoculants. Microbial Biotechnol. 11, 277-301. doi: 10. 1111/1751-7915.12880

Billi, D., Wright, D. J., Helm, R. F., Prickett, T., Potts, M., and Crowe, J. H. (2000). Engineering desiccation tolerance in Escherichia coli. Appl. Environ. Microbiol. 66, 1680-1684. doi: 10.1128/AEM.66.4.1680-1684.2000

Bittner, L., Arends, J., and Narberhaus, F. (2016). Mini review: ATP-dependent proteases in bacteria. Biopolymers 105, 505-517. doi: 10.1002/bip.22831

Boes, N., Schreiber, K., and Schobert, M. (2008). SpoT-triggered stringent response controls usp gene expression in Pseudomonas aeruginosa. J. Bacteriol. 190, 7189-7199. doi: 10.1128/jb.00600-08

Brown, M. R. W., Kornberg, A., and Joyce, G. (2004). Inorganic polyphosphate in the origin and survival of species. PNAS 101, 16085-16087. doi: 10.1073/pnas. 0406909101

Bruijn, I. D., and Raaijmakers, J. M. (2009). Regulation of cyclic lipopeptide biosynthesis in Pseudomonas fluorescens by the ClpP protease. J. Bacteriol. 191, 1910-1923. doi: 10.1128/JB.01558-08

Byrd, M. S., Sadovskaya, I., Vinogradov, E., Lu, H., Sprinkle, A. B., Richardson, S. H., et al. (2009). Genetic and biochemical analyses of the Pseudomonas aeruginosa psl exopolysaccharide reveal overlapping roles for polysaccharide synthesis enzymes in psl and LPS production. Mol. Microbiol. 73, 622-638. doi: 10.1111/j.1365-2958.2009.06795.x

Cabrefiga, J., Francés, J., Montesinos, E., and Bonaterra, A. (2014). Improvement of a dry formulation of Pseudomonas fluorescens EPS62e for fire blight disease biocontrol by combination of culture osmoadaptation with a freeze-drying lyoprotectant. J. Appl. Microbiol. 117, 1122-1131. doi: 10.1111/jam.12582

Cagliero, C., and Jin, D. J. (2013). Dissociation and re-association of RNA polymerase with DNA during osmotic stress response in Escherichia coli. Nucleic Acids Res. 41, 315-326. doi: 10.1093/nar/gks988

Cao-Hoang, L., Dumont, F., Marechal, P. A., Le-Thanh, M., and Gervais, P. (2008). Rates of chilling to $0^{\circ} \mathrm{C}$ : Implications for the survival of microorganisms and relationship with membrane fluidity modifications. Appl. Microbiol. Biotechnol. 77, 1379-1387. doi: 10.1007/s00253-007-1279-z

Cebrián, G., Condón, S., and Mañas, P. (2017). Physiology of the inactivation of vegetative bacteria by thermal treatments: Mode of action, influence of environmental factors and inactivation kinetics. Foods 6:107. doi: 10.3390/ foods6120107

Champagne, C. P., Gardner, N., Brochu, E., and Beaulieu, Y. (1991). The freezedrying of lactic acid bacteria. A review. Can. Instit. Food Sci. Technol. J. 24, 118-128. doi: 10.1016/S0315-5463(91)70034-5

Chan, K., Priya, K., Chang, C., Abdul Rahman, A. Y., Tee, K. K., and Yin, W. (2016). Transcriptome analysis of Pseudomonas aeruginosa PAO1 grown at both body and elevated temperatures. PeerJ 4:e2223. doi: 10.7717/peerj.2223

Chang, W., van de Mortel, M., Nielsen, L., Nino, de Guzman, G., Li, X., et al. (2007). Alginate production by Pseudomonas putida creates a hydrated microenvironment and contributes to biofilm architecture and stress tolerance under water-limiting conditions. J. Bacteriol. 189, 8290-8299. doi: 10.1128/jb. 00727-07

Chin-A-Woeng, T. F. C., Bloemberg, G. V., and Lugtenberg, B. J. J. (2003). Phenazines and their role in biocontrol by Pseudomonas bacteria. N. Phytol. 157, 503-523. doi: 10.1046/j.1469-8137.2003.00686.x

Chong, H., and Li, Q. (2017). Microbial production of rhamnolipids: Opportunities, challenges and strategies. Microb. Cell Factor. 16, 137-137.

Chrzanowski, Ł, Ławniczak, Ł, and Czaczyk, K. (2012). Why do microorganisms produce rhamnolipids? World J. Microbiol. Biotechnol. 28, 401-419. doi: 10. 1007/s11274-011-0854-8

Cid, F. P., Rilling, J. I., Graether, S. P., Bravo, L. A., Mora, María, et al. (2016). Properties and biotechnological applications of ice-binding proteins in bacteria. FEMS Microbiol. Lett. 363:fnw099. doi: 10.1093/femsle/fnw099

Clarke, L., Moore, J. E., Millar, B. C., Garske, L., Xu, J., Heuzenroeder, M. W., et al. (2003). Development of a diagnostic PCR assay that targets a heat-shock protein gene (groES) for detection of Pseudomonas spp. in cystic fibrosis patients. J. Med. Microbiol. 52, 759-763. doi: 10.1099/jmm.0.05077-0

Collin, M., and Schuch, R. (eds) (2009). Bacterial sensing and signaling. Poland: ProQuest Ebook Central.

Davis, C. (2014). Enumeration of probiotic strains: Review of culture-dependent and alternative techniques to quantify viable bacteria. J. Microbiol. Methods 103, 9-17. doi: 10.1016/j.mimet.2014.04.012

De Maayer, P., Anderson, D., Cary, C., and Cowan, D. A. (2014). Some like it cold: Understanding the survival strategies of psychrophiles. EMBO Rep. 15, 508-517. doi: 10.1002/embr.201338170

Díaz-Salazar, C., Calero, P., Espinosa-Portero, R., Jiménez-Fernández, A., Wirebrand, L., Velasco-Domínguez, M. G., et al. (2017). The stringent response promotes biofilm dispersal in Pseudomonas putida. Sci. Rep. 7, 18055-18055. doi: 10.1038/s41598-017-18518-0

Dubern, J., Lagendijk, E. L., Ben, J. J., Lugtenberg, and Bloemberg, G. V. (2005). The heat shock genes dnaK, dnaJ, and grpE are involved in regulation of putisolvin biosynthesis in Pseudomonas putida PCL1445. J. Bacteriol. 187, 5967-5976. doi: 10.1128/JB.187.17.5967-5976.2005

Dziewit, L., Grzesiak, J., Ciok, A., Nieckarz, M., Zdanowski, M. K., and Bartosik, D. (2013). Sequence determination and analysis of three plasmids of Pseudomonas sp. GLE121, a psychrophile isolated from surface ice of ecology glacier (antarctica). Plasmid 70, 254-262. doi: 10.1016/j.plasmid.2013.05.007

Eheth, J. S., Djimeli, C. L., Nana, P. A., Arfao, A. T., Ewoti, O. V. N., Moungang, L. M., et al. (2019). Less effect of wells physicochemical properties on the antimicrobial susceptibility Pseudomonas aeruginosa isolated in equatorial region of central Africa. Appl. Water Sci. 9, 1-9. doi: 10.1007/s13201-0190909-9 
Errampalli, D., and Brubacher, N. R. (2006). Biological and integrated control of postharvest blue mold (Penicillium expansum) of apples by Pseudomonas syringae and cyprodinil. Biol. Contr. 36, 49-56. doi: 10.1016/j.biocontrol.2005. 07.011

Esbelin, J., Santos, T., and Hébraud, M. (2018). Desiccation: An environmental and food industry stress that bacteria commonly face. Food Microbiol. 69, 82-88. doi: 10.1016/j.fm.2017.07.017

Fellows, P. J. (2009). Freeze drying and freeze concentration, 3rd Edn. Cambridge: Woodhead Publishing, 1-2.

Fernandes, M. R., Sellera, F. P., Moura, Q., Carvalho, M. P. N., Rosato, P. N., Cerdeira, L., et al. (2018). Zooanthroponotic transmission of drug-resistant Pseudomonas aeruginosa, brazil. Emerg. Infect. Dis. 24, 1160-1162. doi: 10.3201/ eid2406.180335

Flemming, H., Neu, T. R., and Wozniak, D. J. (2007). The EPS matrix: The "house of biofilm cells". J. Bacteriol. 189, 7945-7947. doi: 10.1128/jb.00858-07

Folkesson, A., Jelsbak, L., Yang, L., Johansen, H. K., Ciofu, O., Høiby, N., et al. (2012). Adaptation of Pseudomonas aeruginosa to the cystic fibrosis airway: An evolutionary perspective. Nat. Rev. Microbiol. 10, 841-851. doi: 10.1038/ nrmicro2907

Frank, S., Schmidt, F., Klockgether, J., Davenport, C. F., Gesell Salazar, M., Völker, U., et al. (2011). Functional genomics of the initial phase of cold adaptation of Pseudomonas putida KT2440. FEMS Microbiol. Lett. 318, 47-54. doi: 10.1111/j. 1574-6968.2011.02237.x

Freeman, B. C., Chen, C., and Beattie, G. A. (2010). Identification of the trehalose biosynthetic loci of Pseudomonas syringae and their contribution to fitness in the phyllosphere. Environ. Microbiol. 12, 1486-1497. doi: 10.1111/j.1462-2920. 2010.02171.x

Freeman, B. C., Chen, C., Yu, X., Nielsen, L., Peterson, K., and Beattie, G. A. (2013). Physiological and transcriptional responses to osmotic stress of two Pseudomonas syringae strains that differ in epiphytic fitness and osmotolerance. J. Bacteriol. 195, 4742-4752. doi: 10.1128/JB.00787-13

Fujita, M., Amemura, A., and Aramaki, H. (1998). Transcription of the groESL operon in Pseudomonas aeruginosa PAO1. FEMS Microbiol. Lett. 163, 237-242. doi: 10.1016/S0378-1097(98)00174-8

Garba, L., Mohamad Ali, M. S., Oslan, S. N., Rahman, Raja Noor, Zaliha Raja, et al. (2016). Molecular cloning and functional expression of a $\Delta 9$ - fatty acid desaturase from an Antarctic Pseudomonas sp. A3. PLoS One 11:e0160681. doi: 10.1371/journal.pone.0160681

Garba, L., Mohamad Yussoff, M. A., Abd Halim, K. B., Ishak, S. N. H., Mohamad Ali, M. S., and Oslan, S. N. (2018). Homology modeling and docking studies of a $\Delta 9$-fatty acid desaturase from a cold-tolerant Pseudomonas sp. AMS8. PeerJ 6:e4347. doi: 10.7717/peerj.4347

Georgescauld, F., Popova, K., Gupta, A., Bracher, A., Engen, J., Hayer-Hartl, M., et al. (2014). GroEL/ES chaperonin modulates the mechanism and accelerates the rate of TIM-barrel domain folding. Cell 157, 922-934. doi: 10.1016/j.cell. 2014.03.038

Gomila, M., Peña, A., Mulet, M., Lalucat, J., and García-Valdés, E. (2015). Phylogenomics and systematics in Pseudomonas. Front. Microbiol. 6:214-214. doi: $10.3389 /$ fmicb.2015.00214

Gray, M. J., and Jakob, U. (2014). Oxidative stress protection by polyphosphate new roles for an old player. Curr. Opin. Microbiol. 24, 1-6. doi: 10.1016/j.mib. 2014.12.004

Gulez, G., Altıntaş, A., Fazli, M., Dechesne, A., Workman, C. T., Tolker-Nielsen, T., et al. (2014). Colony morphology and transcriptome profiling of Pseudomonas putida KT2440 and its mutants deficient in alginate or all EPS synthesis under controlled matric potentials. MicrobiologyOpen 3, 457-469. doi: $10.1002 / \mathrm{mbo} 3.180$

Hadi, R., Vickery, K., Deva, A., and Charlton, T. (2009). Biofilm removal by medical device cleaners: Comparison of two bioreactor detection assays. J. Hospit. Infect. 74, 160-167. doi: 10.1016/j.jhin.2009.10.023

Hall, B. M., Breidenstein, E. B. M., de la Fuente-Núñez, C., Reffuveille, F., Mawla, G. D., Hancock, R. E. W., et al. (2017). Two isoforms of clp peptidase in Pseudomonas aeruginosa control distinct aspects of cellular physiology. J. Bacteriol. 199:16. doi: 10.1128/jb.00568-16

Han, X., Xu, H., Zhu, J., Mao, Y., Hu, J., Zhu, J., et al. (2019). Clinical characteristics and drug tolerance for Pseudomonas aeruginosa infection in patients with agranulocytosis and fever in shanghai. Eur. J. Inflamm. 17:205873921882494. doi: $10.1177 / 2058739218824946$
Heipieper, H. J., Meinhardt, F., and Segura, A. (2003). The cis-trans isomerase of unsaturated fatty acids in Pseudomonas and vibrio: Biochemistry, molecular biology and physiological function of a unique stress adaptive mechanism. Oxford: Elsevier, doi: 10.1016/S0378-1097(03)00792-4

Hentzer, M., Teitzel, G. M., Balzer, G. J., Heydorn, A., Molin, S., Givskov, M., et al. (2001). Alginate overproduction affects Pseudomonas aeruginosa biofilm structure and function. J. Bacteriol. 183, 5395-5401. doi: 10.1128/jb.183.18. 5395-5401.2001

Huang, J., Ji, M., Xie, Y., Wang, S., He, Y., and Ran, J. (2015). Global semiarid climate change over last 60 years. Clim. Dynamics 46, 1131-1150. doi: 10.1007/s00382-015-2636-8

Huang, R., Feng, Z., Chi, X., Sun, X., Lu, Y., Zhang, B., et al. (2018). Pyrrolnitrin is more essential than phenazines for Pseudomonas chlororaphis G05 in its suppression of fusarium graminearum. Microbiol. Res. 215, 55-64. doi: 10.1016/ j.micres.2018.06.008

Huq, T., Khan, A., Khan, R. A., Riedl, B., and Lacroix, M. (2013). Encapsulation of probiotic bacteria in biopolymeric system. Crit. Rev. Food Sci. Nutrit. 53, 909-916. doi: 10.1080/10408398.2011.573152

Ito, F., Tamiya, T., Ohtsu, I., Fujimura, M., and Fukumori, F. (2014). Genetic and phenotypic characterization of the heat shock response in Pseudomonas putida. MicrobiologyOpen 3, 922-936. doi: 10.1002/mbo3.217

Jain, N. K., and Roy, I. (2009). Effect of trehalose on protein structure. Protein Sci. 18, 24-36. doi: 10.1002/pro.3

Kadmiri, M. K., Mernissi, N. E., Azaroual, S. E., Mekhzoum, M. E., Qaiss, A. E., and Bouhfid, R. (2020). Bioformulation of microbial fertilizer based on clay and alginate encapsulation. Curr. Microbiol. 78, 86-94. doi: 10.1007/s00284-02002262-2

Kawahara, H., Li, J., Griffith, M., and Glick, B. R. (2001). Relationship between antifreeze protein and freezing resistance in Pseudomonas putida GR12-2. Curr. Microbiol. 43, 365-370. doi: 10.1007/s002840010317

Kawahara, H., Nakano, Y., Omiya, K., Muryoi, N., Nishikawa, J., and Obata, H. (2004). Production of two types of ice crystal-controlling proteins in antarctic bacterium. J. Biosci. Bioengine. 98, 220-223. doi: 10.1016/S1389-1723(04) 00271-3

Khakimova, M., Ahlgren, H. G., Harrison, J. J., English, A. M., and Nguyen, D. (2013). The stringent response controls catalases in Pseudomonas aeruginosa and is required for hydrogen peroxide and antibiotic tolerance. J. Bacteriol. 195, 2011-2020. doi: 10.1128/jb.02061-12

Khan, M., Bajpai, V. K., Anasari, S. A., Kumar, A., and Goel, R. (2003). Characterization and localization of fluorescent Pseudomonas cold shock protein(s) by monospecific polyclonal antibodies. Microbiol. Immunol. 47, 895-901. doi: 10.1111/j.1348-0421.2003.tb03456.x

Kirstein, J., Molière, N., Turgay, K., and Dougan, D. A. (2009). Adapting the machine: Adaptor proteins for Hsp100/Clp and AAA+ proteases. Nat. Rev. Microbiol. 7, 589-599. doi: 10.1038/nrmicro2185

Klinkert, B., and Narberhaus, F. (2009). Microbial thermosensors. Cell. Mol. Life Sci. 66, 2661-2676. doi: 10.1007/s00018-009-0041-3

Krajewski, S. S., Nagel, M., and Narberhaus, F. (2013). Short ROSE-like RNA thermometers control IbpA synthesis in Pseudomonas species. PLoS One 8:e65168. doi: 10.1371/journal.pone.0065168

Kuhn, E. (2012). Toward understanding life under subzero conditions: The significance of exploring psychrophilic "Cold-shock" proteins. Astrobiology 12, 178-1086. doi: 10.1089/ast.2012.0858

Kumar, S., Suyal, D. C., Yadav, A., Shouche, Y., and Goel, R. (2020). Psychrophilic Pseudomonas helmanticensis proteome under simulated cold stress. Cell Stress Chaperones 25, 1025-1032. doi: 10.1007/s12192-020-01139-4

Kurz, M., Burch, A. Y., Seip, B., Lindow, S. E., and Gross, H. (2010). Genome-driven investigation of compatible solute biosynthesis pathways of Pseudomonas syringae pv. syringae and their contribution to water stress tolerance. Appl. Environ. Microbiol. 76, 5452-5462. doi: 10.1128/AEM.00686- 10

Laue, H., Schenk, A., Li, H., Lambertsen, L., Neu, T. R., Molin, S., et al. (2006). Contribution of alginate and levan production to biofilm formation by Pseudomonas syringae. Microbiology 152, 2909-2918. doi: 10.1099/mic.0. 28875-0

Lawless, C., and Hubbard, S. (2014). "Analysis of Chaperone Network Throughput," in The Molecular Chaperones Interaction Networks in Protein Folding and Degradation. Interactomics and Systems Biology, Vol. 1, ed. W. Houry (New York, NY: Springer). 
Lebre, P. H., De Maayer, P., and Cowan, D. A. (2017). Xerotolerant bacteria: Surviving through a dry spell. Nat. Rev. Microbiol. 15, 285-296. doi: 10.1038/ nrmicro.2017.16

Lee, J., Cho, Y., Yang, J. Y., Jung, Y., Hong, S. G., and Kim, O. (2017). Complete genome sequence of Pseudomonas antarctica PAMC 27494, a bacteriocinproducing psychrophile isolated from antarctica. J. Biotechnol. 259, 15-18. doi: 10.1016/j.jbiotec.2017.08.013

Lee, J., Lee, K., Kim, C., Lee, S., Kim, G., Park, Y., et al. (2005). Cloning and expression of a trehalose synthase from Pseudomonas stutzeri CJ38 in Escherichia coli for the production of trehalose. Appl. Microbiol. Biotechnol. 68, 213-219. doi: 10.1007/s00253-004-1862-5

Li, L., Mendis, N., Trigui, H., Oliver, J. D., and Faucher, S. P. (2014). The importance of the viable but non-culturable state in human bacterial pathogens. Front. Microbiol. 5:258-258. doi: 10.3389/fmicb.2014.00258

Liu, S., He, L., and Yao, K. (2018). The antioxidative function of alpha-ketoglutarate and its applications. BioMed Res. Int. 2018, 1-6. doi: 10.1155/2018/3408467

Lopez, D., Vlamakis, H., and Kolter, R. (2010). biofilms. Cold Spring Harb. Perspect. Biol. 2:a000398. doi: 10.1101/cshperspect.a000398

Lowder, M., Unge, A., Maraha, N., Jansson, J. K., Swiggett, J., and Oliver, J. D. (2000). Effect of starvation and the viable-but-nonculturable state on green fluorescent protein (GFP) fluorescence in GFP-tagged Pseudomonas fluorescens A506. Appl. Environ. Microbiol. 66, 3160-3165. doi: 10.1128/aem.66.8.31603165.2000

Ma, L., Wang, S., Wang, D., Parsek, M. R., and Wozniak, D. J. (2012). The roles of biofilm matrix polysaccharide psl in mucoid Pseudomonas aeruginosa biofilms. FEMS Immunol. Med. Microbiol. 65, 377-380. doi: 10.1111/j.1574-695X.2012. 00934.x

Mailloux, R. J., Singh, R., Brewer, G., Auger, C., Lemire, J., and Appanna, V. D. (2009). $\alpha$-ketoglutarate dehydrogenase and glutamate dehydrogenase work in tandem to modulate the antioxidant $\alpha$-ketoglutarate during oxidative stress in Pseudomonas fluorescens. J. Bacteriol. 191, 3804-3810. doi: 10.1128/JB.00 046-09

Manaia, C. M., and Moore, E. (2002). Pseudomonas thermotolerans sp. nov., a thermotolerant species of the genus Pseudomonas sensu stricto. Int. J. Systemat. Evolut. Microbiol. 52, 2203-2209. doi: 10.1099/00207713-52-6-2203

Mann, E. E., and Wozniak, D. J. (2012). Pseudomonas biofilm matrix composition and niche biology. FEMS Microbiol. Rev. 36, 893-916. doi: 10.1111/j.1574-6976. 2011.00322.x

Manuel, J., Berry, C., Selin, C., Fernando, W. G., and de Kievit, T. R. (2011). Repression of the antifungal activity of Pseudomonas sp. strain DF41 by the stringent response. Appl. Environ. Microbiol. 77, 5635-5642. doi: 10.1128/AEM. 02875- 10

Manuel, J., Selin, C., Fernando, W. G. D., and de Kievit, T. (2012). Stringent response mutants of Pseudomonas chlororaphis PA23 exhibit enhanced antifungal activity against Sclerotinia sclerotiorum in vitro. Microbiology 158, 207-216. doi: 10.1099/mic.0.053082-0

Marchand, S., Heylen, K., Messens, W., Coudijzer, K., De Vos, P., Dewettinck, K., et al. (2009). Seasonal influence on heat-resistant proteolytic capacity of Pseudomonas lundensis and Pseudomonas fragi, predominant milk spoilers isolated from Belgian raw milk samples. Environ. Microbiol. 11, 467-482. doi: 10.1111/j.1462-2920.2008.01785.x

Marshall, D. C., Arruda, B. E., and Silby, M. W. (2019). Alginate genes are required for optimal soil colonization and persistence by Pseudomonas fluorescens Pf0-1. Access Microbiol. 1:e000021.

Mayer, M. P., Rüdiger, S., and Bukau, B. (2000). Molecular basis for interactions of the DnaK chaperone with substrates. Biol. Chem. 381:877.

Mensink, M. A., Frijlink, H. W., van der Voort, Maarschalk, Kees, and Hinrichs, W. L. J. (2017). How sugars protect proteins in the solid state and during drying (review): Mechanisms of stabilization in relation to stress conditions. Eur. J. Pharmaceut. Biopharmaceut. 114, 288-295. doi: 10.1016/j.ejpb.2017.01.024

Meyer, A. S., and Baker, T. A. (2011). Proteolysis in the Escherichia coli heat shock response: A player at many levels. Curr. Opin. Microbiol. 14, 194-199. doi: 10.1016/j.mib.2011.02.001

Mikkat, S., Galinski, E. A., Berg, G., Minkwitz, A., and Schoor, A. (2000). Salt adaptation in pseudomonads: Characterization of glucosylglycerol-synthesizing isolates from brackish coastal waters and the rhizosphere. Syst. Appl. Microbiol. 23, 31-40. doi: 10.1016/s0723-2020(00)80043-0
Morris, C. E., Sands, D. C., Vinatzer, B. A., Glaux, C., Guilbaud, C., Buffière, A., et al. (2008). The life history of the plant pathogen Pseudomonas syringae is linked to the water cycle. ISME J. 2, 321-334. doi: 10.1038/ismej.2007.113

Muryoi, N., Sato, M., Kaneko, S., Kawahara, H., Obata, H., Yaish, M. W. F., et al. (2004). Cloning and expression of afpA, a gene encoding an antifreeze protein from the arctic plant growth-promoting rhizobacterium Pseudomonas putida GR12-2. J. Bacteriol. 186, 5661-5671. doi: 10.1128/jb.186.17.5661-5671.2004

Nakahigashi, K., Yanagi, H., and Yura, T. (1998). Regulatory conservation and divergence of $\varsigma 32$ homologs from gram-negative bacteria: Serratia marcescens, proteus mirabilis, Pseudomonas aeruginosa, and agrobacterium tumefaciens. J. Bacteriol. 180, 2402-2408. doi: 10.1128/JB.180.9.2402-2408.1998

Nakaminami, K., Karlson, D. T., and Imai, R. (2006). Functional conservation of cold shock domains in bacteria and higher plants. PNAS 103, 10122-10127. doi: $10.1073 /$ pnas. 0603168103

Narberhaus, F. (2010). Translational control of bacterial heat shock and virulence genes by temperature-sensing mRNAs. RNA Biol. 7, 84-89. doi: 10.4161/rna.7. 1.10501

Nikel, P. I., Chavarría, M., Martínez-García, E., Taylor, A. C., and de Lorenzo, V. (2013). Accumulation of inorganic polyphosphate enables stress endurance and catalytic vigour in Pseudomonas putida KT2440. Microbial Cell Factor. 12:50. doi: 10.1186/1475-2859-12-50

Nocker, A., Krstulovic, N. P., Perret, X., and Narberhaus, F. (2001). ROSE elements occur in disparate rhizobia and are functionally interchangeable between species. Arch. Microbiol. 176, 44-51. doi: 10.1007/s002030100294

Noll, P., Treinen, C., Müller, S., Senkalla, S., Lilge, L., Hausmann, R., et al. (2019). Evaluating temperature-induced regulation of a ROSE-like RNA-thermometer for heterologous rhamnolipid production in Pseudomonas putida KT2440. $A M B$ Express 9, 1-10.

Ogura, T., and Wilkinson, A. J. (2001). AAA+ superfamily ATPases: Common structure-diverse function. Genes Cells Devoted Mol. Cell. Mechanis. 6, 575-597. doi: 10.1046/j.1365-2443.2001.00447.x

Otero-Asman, J. R., Wettstadt, S., Bernal, P., and Llamas, M. A. (2019). Diversity of extracytoplasmic function sigma $(\sigma$ ECF) factor-dependent signaling in Pseudomonas. Mol. Microbiol. 112, 356-373. doi: 10.1111/mmi.14331

Panicker, G., Panicker, G., Mojib, N., Mojib, N., Nakatsuji, T., Nakatsuji, T., et al. (2010). Occurrence and distribution of capB in Antarctic microorganisms and study of its structure and regulation in the Antarctic biodegradative Pseudomonas sp. 30/3. Extremophiles 14, 171-183. doi: 10.1007/s00792-0090296-5

Park, H. C., Bae, Y. U., Cho, S. D., Kim, S. A., Moon, J. Y., Ha, K. C., et al. (2007). Toluene-induced accumulation of trehalose by Pseudomonas sp. BCNU 106 through the expression of otsA and otsB homologues. Lett. Appl. Microbiol. 44, 50-55. doi: 10.1111/j.1472-765X.2006.02036.x

Parte, A. C. (2018). LPSN - List of Prokaryotic names with Standing in Nomenclature (bacterio.net), 20 years on. Int. J. Systemat. Evolution. Microbiol. 68, 1825-1829. doi: 10.1099/ijsem.0.002786

Pazos-Rojas, L. A., Muñoz-Arenas, L. C., Rodríguez-Andrade, O., López-Cruz, L. E., López-Ortega, O., Lopes-Olivares, F., et al. (2019). Desiccation-induced viable but nonculturable state in Pseudomonas putida KT2440, a survival strategy. PLoS One 14:e0219554. doi: 10.1371/journal.pone.0219554

Phadtare, S., and Inouye, M. (2004). Genome-wide transcriptional analysis of the cold shock response in wild-type and cold-sensitive, quadruple-csp-deletion strains of Escherichia coli. J. Bacteriol. 186, 7007-7014. doi: 10.1128/jb.186.20. 7007-7014.2004

Pletzer, D., Coleman, S. R., and Hancock, R. E. (2016). Anti-biofilm peptides as a new weapon in antimicrobial warfare. Curr. Opin. Microbiol. 33, 35-40. doi: 10.1016/j.mib.2016.05.016

Potvin, E., Sanschagrin, F., and Levesque, R. C. (2008). Sigma factors in Pseudomonas aeruginosa. FEMS Microbiol. Rev. 32, 38-55. doi: 10.1111/j.15746976.2007.00092.x

Pour, M. M., Saberi-Riseh, R., Mohammadinejad, R., and Hosseini, A. (2019). Investigating the formulation of alginate- gelatin encapsulated Pseudomonas fluorescens (VUPF5 and T17-4 strains) for controlling fusarium solani on potato. Int. J. Biol. Macromol. 133, 603-613. doi: 10.1016/j.ijbiomac.2019.04.071

Power, B., Liu, X., Germaine, K. J., Ryan, D., Brazil, D., and Dowling, D. N. (2011). Alginate beads as a storage, delivery and containment system for genetically modified PCB degrader and PCB biosensor derivatives of Pseudomonas 
fluorescens F113. J. Appl. Microbiol. 110, 1351-1358. doi: 10.1111/j.1365-2672. 2011.04993.x

Pravisya, P., Jayaram, K. M., and Yusuf, A. (2018). Biotic priming with Pseudomonas fluorescens induce drought stress tolerance in abelmoschus esculentus (L.) moench (okra). Physiol. Mol. Biol. Plants 25, 101-112. doi: 10.1007/s12298-018-0621-5

Priebe, G. P., and Goldberg, J. B. (2014). Vaccines for Pseudomonas aeruginosa: A long and winding road. Expert Rev. Vaccines 13, 507-519. doi: 10.1586/ 14760584.2014.890053

Qiu, D., Eisinger, V. M., Head, N. E., Pier, G. B., and Yu, H. D. (2008). ClpXP proteases positively regulate alginate overexpression and mucoid conversion in Pseudomonas aeruginosa. Microbiology 154, 2119-2130. doi: 10.1099/mic.0. 2008/017368-0

Raaijmakers, J. M., Bruijn, D. I, Nybroe, O., and Ongena, M. (2010). Natural functions of lipopeptides from Bacillus and Pseudomonas: More than surfactants and antibiotics. FEMS Microbiol. Rev. 34, 1037-1062. doi: 10.1111/ j.1574-6976.2010.00221.x

Ramos, J. L., Gallegos, M., Marqués, S., Ramos-González, M., Espinosa-Urgel, M., and Segura, A. (2001). Responses of gram-negative bacteria to certain environmental stressors. Amsterdam: Elsevier Ltd, doi: 10.1016/S1369-5274(00) 00183-1

Raudales, R. E., Parke, J. L., Guy, C. L., and Fisher, P. R. (2014). Control of waterborne microbes in irrigation: A review. Agricult. Water Manage. 143, 9-28. doi: 10.1016/j.agwat.2014.06.007

Rich, J. O., Leathers, T. D., Bischoff, K. M., Anderson, A. M., and Nunnally, M. S. (2015). Biofilm formation and ethanol inhibition by bacterial contaminants of biofuel fermentation. Bioresour. Technol. 196, 347-354. doi: 10.1016/j.biortech. 2015.07.071

Richter, K., Haslbeck, M., and Buchner, J. (2010). The heat shock response: Life on the verge of death. Mol. Cell 40, 253-266. doi: 10.1016/j.molcel.2010. 10.006

Rolli, E., Marasco, R., Vigani, G., Ettoumi, B., Mapelli, F., Deangelis, M. L., et al. (2015). Improved plant resistance to drought is promoted by the root-associated microbiome as a water stress-dependent trait. Environ. Microbiol. 17, 316-331. doi: 10.1111/1462-2920.12439

Roy, R., Tiwari, M., Donelli, G., and Tiwari, V. (2018). Strategies for combating bacterial biofilms: A focus on anti-biofilm agents and their mechanisms of action. Virulence 9, 522-554. doi: 10.1080/21505594.2017.1313372

Russell, A. D. (2003). Lethal effects of heat on bacterial physiology and structure. Sci. Prog. 86, 115-137. doi: 10.3184/003685003783238699

Sandhya, V., Ali, S. Z., Grover, M., Reddy, G., and Venkateswarlu, B. (2010). Effect of plant growth promoting Pseudomonas spp. on compatible solutes, antioxidant status and plant growth of maize under drought stress. Plant Growth Regulat. 62, 21-30. doi: 10.1007/s10725-010-9479-4

Schafhauser, J., Lepine, F., McKay, G., Ahlgren, H. G., Khakimova, M., and Nguyen, D. (2014). The stringent response modulates 4-hydroxy-2-alkylquinoline biosynthesis and quorum-sensing hierarchy in Pseudomonas aeruginosa. J. Bacteriol. 196, 1641-1650. doi: 10.1128/jb.01086-13

Schiraldi, C., Di Lernia, I., and De Rosa, M. (2002). Trehalose production: Exploiting novel approaches. Trends Biotechnol. 20, 420-425. doi: 10.1016/ s0167-7799(02)02041-3

Schisler, D. A., Slininger, P. J., and Olsen, N. L. (2016). Appraisal of selected osmoprotectants and carriers for formulating gram-negative biocontrol agents active against fusarium dry rot on potatoes in storage. Biol. Contr. 98, 1-10. doi: 10.1016/j.biocontrol.2016.03.009

Schnider-Keel, U., Lejbølle, K. B., Baehler, E., Haas, D., and Keel, C. (2001). The sigma factor $\mathrm{AlgU}$ ( $\mathrm{Alg} \mathrm{T}$ ) controls exopolysaccharide production and tolerance towards desiccation and osmotic stress in the biocontrol agent Pseudomonas fluorescens CHA0. Appl. Environ. Microbiol. 67, 5683-5693. doi: 10.1128/AEM. 67.12.5683-5693.2001

Schuster, M., Hawkins, A. C., Harwood, C. S., and Greenberg, E. P. (2004). The Pseudomonas aeruginosa RpoS regulon and its relationship to quorum sensing. Mol. Microbiol. 51, 973-985. doi: 10.1046/j.1365-2958.2003.03886.x

Shivaji, S., and Prakash, J. S. S. (2010). How do bacteria sense and respond to low temperature? Arch. Microbiol. 192, 85-95. doi: 10.1007/s00203-009-0539-y

Silby, M. W., Nicoll, J. S., and Levy, S. B. (2009). Requirement of polyphosphate by Pseudomonas fluorescens Pf0-1 for competitive fitness and heat tolerance in laboratory media and sterile soil. Appl. Environ. Microbiol. 75, 3872-3881. doi: 10.1128/AEM.00017-09

Singh, B., and Gupta, R. S. (2009). Conserved inserts in the Hsp60 (GroEL) and Hsp70 (DnaK) proteins are essential for cellular growth. Mol. Genet. Genomics MGG 281, 361-373. doi: 10.1007/s00438-008-0417-3

Singh, P., Hanada, Y., Singh, S. M., and Tsuda, S. (2014). Antifreeze protein activity in arctic cryoconite bacteria. FEMS Microbiol. Lett. 351, 14-22. doi: 10.1111/ 1574-6968.12345

Sleight, S., and Lenski, R. (2007). Evolutionary adaptation to Freeze-Thaw-Growth cycles in Escherichia coli. Physiol. Biochem. Zool. 80, 370-385. doi: 10.1086/518013

Snider, J., Thibault, G., and Houry, W. A. (2008). The AAA+ superfamily of functionally diverse proteins. Genome Biol. 9, 216-216. doi: 10.1186/gb-20089-4-216

Stoeckel, M., Lidolt, M., Achberger, V., Glück, C., Krewinkel, M., Stressler, T., et al. (2016). Growth of Pseudomonas weihenstephanensis, Pseudomonas proteolytica and Pseudomonas sp. in raw milk: Impact of residual heat-stable enzyme activity on stability of UHT milk during shelf-life. Int. Dairy J. 59, 20-28. doi: 10.1016/ j.idairyj.2016.02.045

Storz, G., and Hengge, R. (2011). Bacterial Stress Responses, 2nd Edn. Washington DC: ASM Press.

Su, X., Chen, X., Hu, J., Shen, C., and Ding, L. (2013). Exploring the potential environmental functions of viable but non-culturable bacteria. World J. Microbiol. Biotechnol. 29, 2213-2218. doi: 10.1007/s11274-013$1390-5$

Subramanian, P., Kim, K., Krishnamoorthy, R., Mageswari, A., Selvakumar, G., and Sa, T. (2016). Cold stress tolerance in psychrotolerant soil bacteria and their conferred chilling resistance in tomato (solanum lycopersicum mill.) under low temperatures. PLoS One 11:e0161592. doi: 10.1371/journal.pone.016 1592

Svenningsen, N. B., Martínez-García, E., Nicolaisen, M. H., de Lorenzo, V., and Nybroe, O. (2018). The biofilm matrix polysaccharides cellulose and alginate both protect $P$ seudomonas putida $\mathrm{mt}-2$ against reactive oxygen species generated under matric stress and copper exposure. Microbiology 164, 883-888. doi: $10.1099 /$ mic. 0.000667

Thakur, P. B., Vaughn-Diaz, V. L., Greenwald, J. W., and Gross, D. C. (2013). Characterization of five ECF sigma factors in the genome of Pseudomonas syringae pv. syringae B728a. PLoS One 8:e58846. doi: 10.1371/journal.pone. 0058846

Traxler, M. F., Summers, S. M., Nguyen, H., Zacharia, V. M., Hightower, G. A., Smith, J. T., et al. (2008). The global, ppGpp-mediated stringent response to amino acid starvation in Escherichia coli. Mol. Microbiol. 68, 1128-1148. doi: 10.1111/j.1365-2958.2008.06229.x

Trevors, J. T., Bej, A. K., Mojib, N., van Elsas, J. D., and Van Overbeek, L. (2012). Bacterial gene expression at low temperatures. Extremoph. Life Under Extreme Condit. 16, 167-176. doi: 10.1007/s00792-011-0423-y

Troxler, J., Svercel, M., Natsch, A., Zala, M., Keel, C., Moënne-Loccoz, Y., et al. (2012). Persistence of a biocontrol Pseudomonas inoculant as high populations of culturable and non-culturable cells in 200-cm-deep soil profiles. Soil Biol. Biochem. 44, 122-129. doi: 10.1016/j.soilbio.2011.09.020

Valencia-Botín, A. J., and Cisneros-López, M. E. (2012). A review of the studies and interactions of Pseudomonas syringae pathovars on wheat. Int. J. Agronomy 2012:692350. doi: 10.1155/2012/692350

Varela, C., Mauriaca, C., Paradela, A., Albar, J. P., Jerez, C. A., and Chávez, F. P. (2010). New structural and functional defects in polyphosphate deficient bacteria: A cellular and proteomic study. BMC Microbiol. 10:7-7. doi: 10.1186/ 1471-2180-10-7

Venketesh, S., and Dayananda, C. (2008). Properties, potentials, and prospects of antifreeze proteins. Crit. Rev. Biotechnol. 28, 57-82. doi: 10.1080/ 07388550801891152

Villeret, V., Beeumen, J. V., Chessa, J., and Gerday, C. (1997). Preliminary crystal structure determination of the alkaline protease from the Antarctic psychrophile Pseudomonas aeruginosa. Protein Sci. 6, 2462-2464. doi: 10.1002/ pro. 5560061121

Vinella, D., Albrecht, C., Cashel, M., and D'Ari, R. (2005). Iron limitation induces SpoT-dependent accumulation of ppGpp in Escherichia coli. Mol. Microbiol. 56, 958-970. doi: 10.1111/j.1365-2958.2005.04601.x 
Vorob'eva, L. I. (2004). Stressors, stress reactions, and survival of bacteria: A review. Appl. Biochem. Microbiol. 40, 217-224. doi: 10.1023/B:ABIM.0000025941. 11643.19

Vyas, P., Rahi, P., and Gulati, A. (2009). Stress tolerance and genetic variability of phosphate-solubilizing fluorescent Pseudomonas from the cold deserts of the trans-himalayas. Microb. Ecol. 58, 425-434. doi: 10.1007/s00248-0099511-2

Wallace, R. L., Hirkala, D. L., and Nelson, L. M. (2017). Postharvest biological control of blue mold of apple by Pseudomonas fluorescens during commercial storage and potential modes of action. Postharv. Biolo. Technol. 133, 1-11. doi: $10.1016 /$ j.postharvbio.2017.07.003

Wang, C. L., Ozuna, S. C., Clark, D. S., and Keasling, J. D. (2002). A deepsea hydrothermal vent isolate, Pseudomonas aeruginosa CW961, requires thiosulfate for Cd2+ tolerance and precipitation. Biotechnol. Lett. 24, 637-641. doi: 10.1023/A:1015043324584

Wang, C., Pakhomova, S., Newcomer, M. E., Christner, B. C., and Luo, B. (2017). Structural basis of antifreeze activity of a bacterial multi-domain antifreeze protein. PLoS One 12:e0187169. doi: 10.1371/journal.pone.0187 169

Wang, T., Jia, S., Dai, K., Liu, H., and Wang, R. (2014). Cloning and expression of a trehalose synthase from Pseudomonas putida KT2440 for the scale-up production of trehalose from maltose. Canad. J. Microbiol. 60, 599-604. doi: 10.1139/cjm-2014-0330

Wang, X., Tang, D., and Wang, W. (2020b). Improvement of a dry formulation of Pseudomonas protegens SN15-2 against ralstonia solanacearum by combination of hyperosmotic cultivation with fluidized-bed drying. BioControl 65:10042-x. doi: 10.1007/s10526-020-10042-x
Wang, X., Tang, D., and Wang, W. (2020a). Hyperosmotic adaptation of Pseudomonas protegens SN15-2 helps cells to survive at lethal temperatures. Biotechnol. Bioproc. Engine. 25, 403-413. doi: 10.1007/s12257-019-0430-x

Wasi, S., Tabrez, S., and Ahmad, M. (2013). Use of Pseudomonas spp. for the bioremediation of environmental pollutants: A review. Environ. Monitor. Assess. 185, 8147-8155. doi: 10.1007/s10661-013-3163-x

Welsh, D. T. (2000). Ecological significance of compatible solute accumulation by micro-organisms: From single cells to global climate. FEMS Microbiol. Rev. 24, 263-290. doi: 10.1016/S0168-6445(99)00038-8

Wu, L., Wang, Z., Guan, Y., Huang, X., Shi, H., Liu, Y., et al. (2020). The (p)ppGpp-mediated stringent response regulatory system globally inhibits primary metabolism and activates secondary metabolism in pseudomonas protegens H78. Appl. Microbiol. Biotechnol. 104, 3061-3079. doi: 10.1007/ s00253-020-10421-5

Conflict of Interest: KC and BJ are employed by the company AgBiome Inc.

The remaining author declares that the research was conducted in the absence of any commercial or financial relationships that could be construed as a potential conflict of interest.

Copyright (c) 2021 Craig, Johnson and Grunden. This is an open-access article distributed under the terms of the Creative Commons Attribution License (CC BY). The use, distribution or reproduction in other forums is permitted, provided the original author(s) and the copyright owner(s) are credited and that the original publication in this journal is cited, in accordance with accepted academic practice. No use, distribution or reproduction is permitted which does not comply with these terms. 